\title{
A Review of Zoonotic Pathogens of Dromedary Camels
}

\author{
Sophie Zhu(1), ${ }^{1}$ Dawn Zimmerman, ${ }^{2}$ and Sharon L. Deem ${ }^{3}$ \\ ${ }^{1}$ Graduate Group in Epidemiology, University of California, Davis, CA 95616 \\ ${ }^{2}$ Global Health Program, Smithsonian Conservation Biology Institute, Washington, DC 20008 \\ ${ }^{3}$ Institute for Conservation Medicine, Saint Louis Zoo, Saint Louis, MO 63110
}

\begin{abstract}
Dromedary, or one-humped, camels Camelus dromedarius are an almost exclusively domesticated species that are common in arid areas as both beasts of burden and production animals for meat and milk. Currently, there are approximately 30 million dromedary camels, with highest numbers in Africa and the Middle East. The hardiness of camels in arid regions has made humans more dependent on them, especially as a stable protein source. Camels also carry and may transmit disease-causing agents to humans and other animals. The ability for camels to act as a point source or vector for disease is a concern due to increasing human demands for meat, lack of biosafety and biosecurity protocols in many regions, and a growth in the interface with wildlife as camel herds become sympatric with non-domestic species. We conducted a literature review of camel-borne zoonotic diseases and found that the majority of publications (65\%) focused on Middle East respiratory syndrome (MERS), brucellosis, Echinococcus granulosus, and Rift Valley fever. The high fatality from MERS outbreaks during 2012-2016 elicited an immediate response from the research community as demonstrated by a surge of MERS-related publications. However, we contend that other camel-borne diseases such as Yersinia pestis, Coxiella burnetii, and Crimean-Congo hemorrhagic fever are just as important to include in surveillance efforts. Camel populations, particularly in sub-Saharan Africa, are increasing exponentially in response to prolonged droughts, and thus, the risk of zoonoses increases as well. In this review, we provide an overview of the major zoonotic diseases present in dromedary camels, their risk to humans, and recommendations to minimize spillover events.
\end{abstract}

Keywords: Camel, Nomadic, One health, Pathogen, Spillover, Zoonoses

\section{INTRODUCTION}

Worldwide there are roughly 30 million dromedary camels, with highest numbers found in Africa and the Middle East (Figure 1). Due to increased consumption and contact with camel meat and milk, camels represent a significant point source for zoonotic disease transmission to humans. Pas-

Published online: May 28, 2019

Correspondence to: Sophie Zhu, e-mail: sozhu@ucdavis.edu toralist camel production, in particular, is associated with a risk of disease spillover from wildlife into camel populations, and from camels to wildlife, as well as less opportunities for disease surveillance and control. By 2050 the human population is projected to grow by 2.5 billion, with nearly half of all population growth occurring in the African continent (Roser 2018). Along with the increase in human population in Africa and the Middle East, the camel population has also experienced steady growth as the de- 


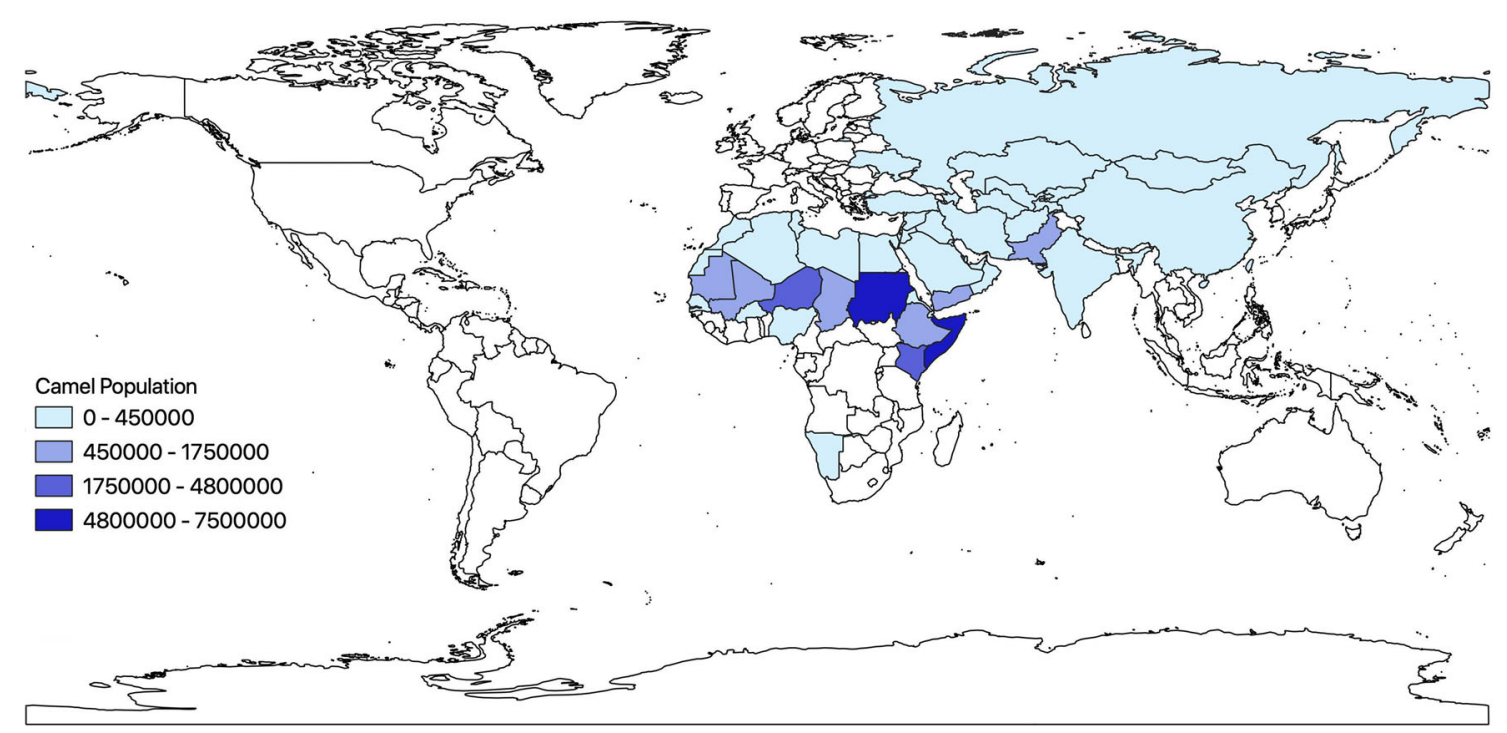

Figure 1. Map of domesticated dromedary camel population by country in 2016; data from Food and Agricultural Organization (Food and Agricultural Organization, 2016)

mand and production of camel meat and milk escalates (FAOSTAT 2016). More and more, nomadic herders are switching to an agricultural or urban setting to raise camels and this change in camel production brings potential risks of disease emergence and transmission. In addition, with the realities of climate change and the increase in drought conditions, camel hardiness has led to a shift in livestock choice in many regions of the world from cattle to camels, making camels even more abundant (Watson et al. 2016)

Limited resources, low levels of regulation, poor hygiene, high mobility of animals and herders, and lack of consistent veterinary care also act as drivers for disease spillover (Gossner et al. 2016; Megersa et al. 2011). Knowledge of camel-borne diseases, clinical signs, and pathways of transmission is thus important to mitigate human risks of camel-associated zoonoses. Many infectious diseases that have been an issue in Africa and the Middle East during the last decades, such as Middle East respiratory syndrome (MERS) and brucellosis, have an association with camel contact (Ahmed et al. 2010; Ferguson and Van Kerkhove 2014). Additionally, novel camel-borne diseases continue to be identified, as best exemplified by reports of a prion disease from Algerian abattoir camels published during the editing of this review paper (Babelhadj et al. 2018)

Significant research on seropositivity and detection of specific diseases of camels, those that have implications for human health, has been conducted; however, to the authors' knowledge no publication has summarized the cur- rent literature on these zoonotic diseases. Realizing the need for a thorough review of the literature to identify the risks that camels pose to human health was the impetus for this review. In this paper, we review publications of the most common confirmed and potential camel zoonoses of interest: bacterial, viral, and parasitic, and offer recommendations for surveillance and control of the diseases of highest priority.

\section{Methods}

We utilized two search engines, Google Scholar and PubMed, to search for publications related to camel-borne disease and zoonotic spillover. We chose Google Scholar for breadth and volume of content, while PubMed was chosen from medical and public health-specific search engines for its specificity. Publications on Bactrian camels Camelus bactrianus were excluded because they are primarily wild but are used as beasts of burden and food in select countries and only account for 2 million out of 30 million total camels (IUCN 2008). To cast a wide net for possible diseases we did not search for specific zoonotic diseases and instead classified publications by disease after the initial literature search. All search terms included the words camel and human as well as one of six other words keywords: camel + human + zoonotic, illness, spillover, outbreak, transmission, or disease. For each set of search terms, we reviewed the first 100 results for relevancy or all results if $<100$. Included publications were restricted to 
those written in English, but there was no date limit, no other restrictions were set, and papers were sorted by relevance. From a total of 1054 papers, 619 were unique or non-duplicates and 304 of these were relevant (Figure 2). Five of these 304 papers reported on multiple diseases. Results that were excluded included papers that inconclusively related to transmission from camels $n=96$, noncamelid animals $n=40$, studies that focused on vaccines $n=25$, camel-specific diseases $n=22$, articles/seminars $n=15$, and non-relevant topics $n=117$. Examples of nonrelevance were papers that did not mention camels at all, papers that did not discuss transmission of disease, papers on human-to-human transmission, or papers that discussed laboratory testing and techniques related to these diseases. Food-borne bacterial diseases from pathogens such as Escherichia coli, Salmonella, and Campylobacter were consolidated into one category termed "food-borne" because they share transmission pathways, have similar symptoms, and were pre-grouped by several publications in this review. We also elected to present these pathogens in this fashion because there was a precedence set by said publications. Papers with positive serologic testing in camels, probable disease through an explained epidemiologic link between human disease and camel-borne pathogens, and isolation of similar strains in humans and camels fit criteria for inclusion. Relevant papers were sorted into bacterial, viral, and parasitic categories along with recorded counts for each disease. Results were separated out in this manner to cover scope number of diseases as well as depth number of papers per disease. Figures were created in Quantum GIS 3.6 (QGIS Development Team 2019). We completed the literature search in February and March of 2018.

\section{Results}

Through this literature review, we identified 304 papers published between 1970 and 2018 that described disease agents in camels with probable (see above definition) or confirmed transmission to humans. Thirty-seven camelborne diseases were identified, comprised of 12 bacterial diseases, 13 viral diseases, and 12 parasitic diseases (Table 1). The most frequently occurring diseases or diseasecausing agents in this study were MERS $n=118$, Echinococcus granulosus $n=46$, brucellosis $n=35$, and Rift Valley fever $n=19$. In this study, 42 countries were represented in the literature, with most papers originating from Saudi Arabia $n=36$, Iran $n=27$, Kenya $n=15$, and Egypt $n=14$ (Figure 3). There has been a dramatic increase in publications over the last eight years with a peak during 2012-2016, when research on MERS was undertaken in a number of laboratories following the first diagnosis of a human fatality reported in 2012 (Fig. 4) (Kupferschmidt 2014).

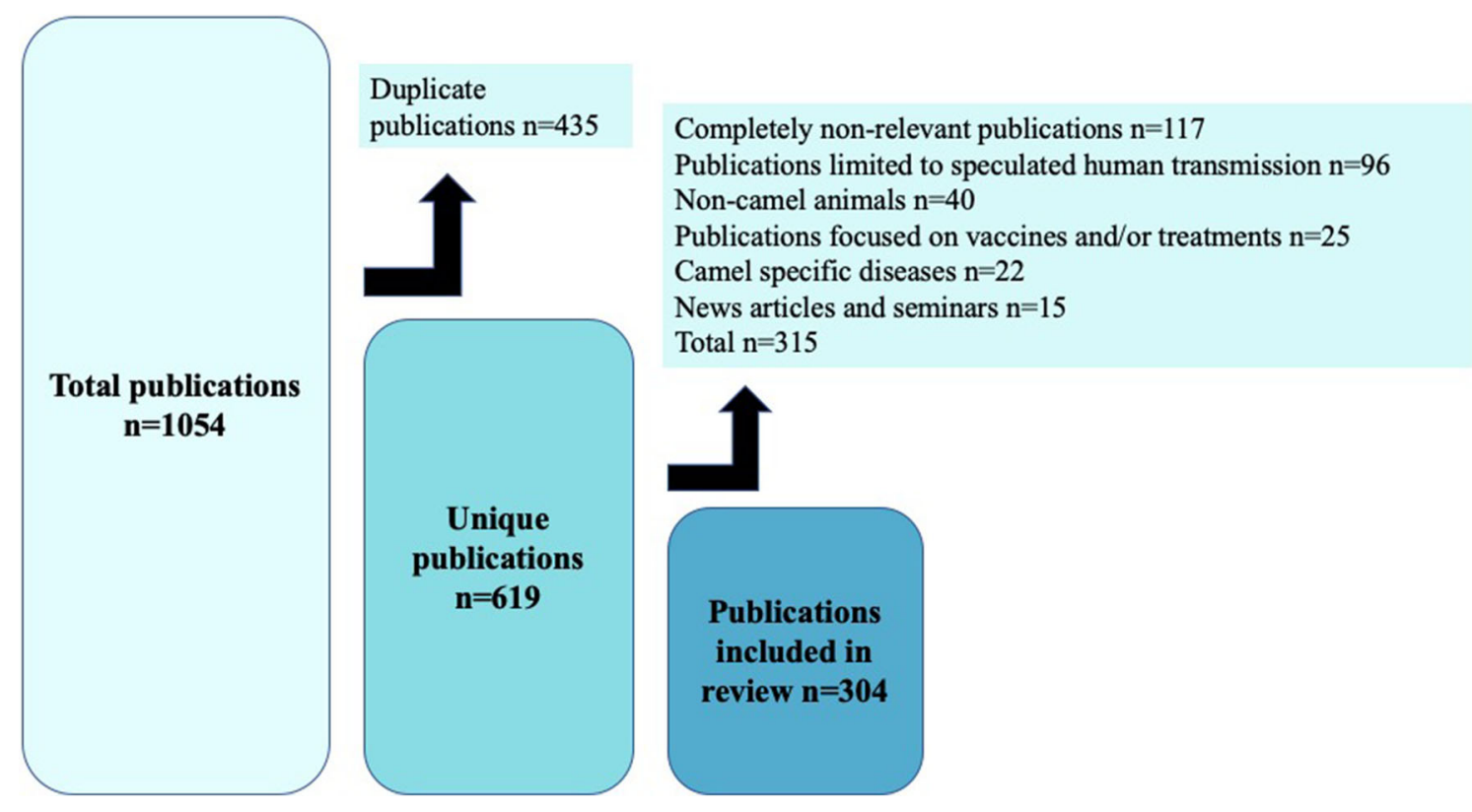

Figure 2. Methodology for inclusion and exclusion of publications of camel-borne zoonoses. Out of an initial 1054 eligible publications, 619 were unique and non-duplicate and 304 of those were included in the final selection of journal articles for further analysis 
Table 1. Camel-borne diseases found in review by paper count

\begin{tabular}{cccc}
\hline Disease/agent & Type & Paper count & Re \\
\hline $\begin{array}{c}\text { Middle East } \\
\text { respiratory } \\
\text { syndrome }\end{array}$ & Virus & 118 & Ad
\end{tabular}

Adney et al. (2014), Ahmed (2017a, b), Al Hammadi et al. (2015), Al salihi and Alrodhan (2017), Al-Tawfiq and Memish (2014a, b), Al-Tawfiq et al. (2014), Alagaili et al. (2014), Aleanizy et al. (2017), Alexandersen et al. (2014), Alhakeem et al. (2016), Alhamlan et al. (2017), Ali et al. (2017), Alraddadi et al. (2016), Alsolamy et al. (2017), Assiri et al. (2016), Azhar et al. (2014a, b), Balkhy et al. (2016), Banik et al. (2015), Buchholz et al. (2013), Chan et al. (2014, 2015), Chu et al. (2014, 2015, 2018), Corman et al. (2014a, b, 2016), Cotten et al. (2013, 2014), Crameri et al. (2015), Deem et al. (2015), Devi et al. (2014), Drosten et al. (2015), Du and Han (2016), Dudas et al. (2018), Durai et al. (2015), Eckerle et al. (2014), El Bushra et al. (2016), Fanoy et al. (2014), Farag et al. (2015), Fehr et al. (2017), Ferguson and Van Kerkhove (2014), Food and Agriculture Organization of the United Nations (2017), Funk et al. (2016), Gardner and MacIntyre (2014), Gossner et al. (2016), Gutiérrez et al. (2015), Haagmans et al. (2014, 2016), Han et al. (2016), Hemida et al. (2013, 2014, 2015, 2017), Holmes (2014), Hunter et al. (2016), Kayali and Peiris (2015), Khalafalla et al. (2015), Kupferschmidt (2015), Liljander et al. (2016), Mackay and Arden (2015, 2017), Majumder (2015), Memish et al. (2013, 2014a, b, 2015), Meyer et al. (2014, 2016), Miguel et al. (2016, 2017), Mohd et al. (2016), Muhairi et al. (2016), Müller et al. (2014, 2015), Ng et al. (2016), Nowotny and Kolodziejek (2014), Oladipo (2015), Olival and Epstein (2015), Omrani et al. (2015), Omrani and Shalhoub (2015), Park et al. (2015), Rabaan (2017), Raj et al. (2014),

Rasmussen et al. (2015, 2016), Reeves et al. (2015), Reusken et al. (2013a, b, 2014a, b, 2015, 2016), Reuss et al. (2014), Sabir et al. (2016), Salkeld et al. (2016), Saqib et al. (2017), Shapiro et al. (2016), Sharif-Yakan and Kanj (2014), Shehata et al. (2016), Su et al. (2016), Tai et al. (2017), Watson et al. (2014), Wernery et al. (2015, 2016), Widagdo et al. (2016), de Wit et al. (2016), de Wit and Munster (2013), World Health Organization (2015), Younan et al. (2016), Yusof et al. (2015), Zhang et al. (2016), Zumla et al. (2015, 2016), Zumla and Memish (2014)

Hydatidosis $\quad$ Parasite 46 (Echinococcus granulosus)

Abdel Aaty et al. (2012), Abushhewa et al. (2010), Ahmadi (2005), Alvarez Rojas et al. (2014), Azab et al. (2004), Bardonnet et al. (2002, 2003), Casulli et al. (2010), Dinkel et al. (2004), Eckert and Deplazes (2004), Eckert et al. (1989), Elmahdi et al. (2004), Hailemariam et al. (2012), Hajialilo et al. (2012), Fasihi Harandi et al. (2002), Hassanain et al. (2016), Kamenetzky et al. (2002), Karimi et al. (2017), Kia et al. (2010), Kinkar et al. (2017), Latif et al. (2010), Macpherson and McManus (1982), Macpherson and Smyth (1985), Maillard et al. (2006), Mandal and Deb Mandal (2012), McManus (1981), McManus and Rishi (1989), Mirzaei et al. (2016), Mobedi et al. (1970), Mrad et al. (2005), Oksanen and Lavikainen (2015), Omer et al. 2010a, b, Sadjjadi (2006), Salem et al. (2011), Shahnazi et al. (2011), Shariatzadeh et al. (2015), Sharma et al. (2013b), Singh et al. (2014), Spotin et al. (2015, 2017), Tigre et al. (2016), Thompson (2008), Utuk et al. (2008), Wachira et al. (1993), Youssef and Uga (2014), Zhang et al. (1998) 
Table 1. continued

\begin{tabular}{|c|c|c|c|}
\hline Disease/agent & Type & $\begin{array}{l}\text { Paper } \\
\text { count }\end{array}$ & References \\
\hline Brucellosis & Bacteria & 35 & $\begin{array}{l}\text { Abbas and Agab (2002), Ahmed et al. (2010), Al Dahouk et al. (2013), Bekele et al. (2013), } \\
\text { Cooper (1992), Ducrotoy et al. (2015), El-Ansary et al. (2001), Fiori et al. (2000), Garcell } \\
\text { et al. (2016), Gautret et al. (2013), Godfroid et al. (2005, 2013), Gumaa et al. (2014), Gwida } \\
\text { et al. (2010, 2012), Kiel and Yousuf (1989), Megersa et al. (2011), Megersa et al. (2012), } \\
\text { Memish and Balkhy (2004), Nimri (2003), Omer et al. 2010a, b, Osoro et al. (2015), } \\
\text { Pappas (2010), Rhodes et al. (2016), Schelling et al. (2003), Schelling et al. (2004), Seleem } \\
\text { et al. (2010), Shaalan et al. (2002), Shimol et al. (2012), Smits and Kadri (2005), Sprague } \\
\text { et al. (2012), Teshome et al. (2003), Wernery (2014), Yahya (2015), Zewolda and Wereta } \\
\text { (2012) }\end{array}$ \\
\hline Rift Valley fever & Virus & 19 & $\begin{array}{l}\text { Abdo-Salem et al. (2006), Ahmed Kamal (2011), Bird et al. (2008), Britch et al. (2013), } \\
\text { Chevalier et al. (2010), Chinikar et al. (2013), El Mamy et al. (2011, 2014), Faye et al. } \\
\text { (2014), Gerdes (2004), Horton et al. (2014), Jäckel et al. (2013), Linthicum et al. (2016), } \\
\text { Lutomiah et al. (2014), Merrill et al. (2015), Macharia et al. (2010), Paweska (2015), Swai } \\
\text { and Sindato (2015), Weaver and Reisen (2010) }\end{array}$ \\
\hline Food-borne & Bacteria & 15 & $\begin{array}{l}\text { Dehkordi et al. (2013), Fadlelmula et al. (2016), Ghoneim et al. (2017), Hajialilo et al. (2012), } \\
\text { Horton et al. (2014), Jaros et al. (2008), Kaindi et al. (2012), Rahimi et al. (2010, 2012), } \\
\text { Rahimi and Kheirabadi (2012), Raufu et al. (2015), Salehi et al. (2012), Shabana et al. } \\
\text { (2013), Sung et al. (2008), Tadesse (2015), Tejedor-Junco et al. (2015) }\end{array}$ \\
\hline $\begin{array}{l}\text { Plague (Yersinia } \\
\text { pestis) }\end{array}$ & Bacteria & 10 & $\begin{array}{l}\text { Aikimbajev et al. (2003), Arbaji et al. (2005), Bramanti et al. (2016), Cabanel et al. (2013), } \\
\text { Christie et al. (1980), Drancourt et al. (2006), El-Bahnasawy et al. (2012), Leslie et al. } \\
\text { (2011), Saeed et al. (2005), Stenseth et al. (2008) }\end{array}$ \\
\hline Camelpox & Virus & 9 & $\begin{array}{l}\text { Balamurugan et al. (2013), Bera et al. (2010, 2011, 2015), Duraffour et al. (2011), Jezek et al. } \\
\text { (1983), Khalafalla and Abdelazim (2017), Pearce-Duvet (2006), Shchelkunov (2013) }\end{array}$ \\
\hline $\begin{array}{l}\text { Q fever (Coxiella } \\
\text { burnetii) }\end{array}$ & Bacteria & 7 & $\begin{array}{l}\text { Klemmer et al. (2018), Mohabbati Mobarez et al. (2017), Njeru et al. (2016), Pirouz et al. } \\
\text { (2015), Schelling et al. (2003, 2004), Vanderburg et al. (2014) }\end{array}$ \\
\hline Linguatula serrata & Parasite & 7 & $\begin{array}{l}\text { Bamorovat et al. (2014), Farjanikish and Shokrani (2016), Haddadzadeh et al. (2010), Oryan } \\
\text { et al. (2011), Rezaei et al. (2012), Sadjjadi et al. (1998), Shakerian et al. (2008) }\end{array}$ \\
\hline Hepatitis E & Virus & 5 & $\begin{array}{l}\text { Khuroo and Khuroo (2016), Lee et al. (2016), Pavio et al. (2015), Rasche et al. (2016), Spahr } \\
\text { et al. (2018) }\end{array}$ \\
\hline $\begin{array}{l}\text { Crimean-Congo } \\
\text { hemorrhagic fever }\end{array}$ & Virus & 4 & Champour et al. (2016), Khan et al. (1997), Mertens et al. (2013), Walker et al. (2016) \\
\hline Tuberculosis & Bacteria & 4 & Cosivi et al. (1995), Garine-Wichatitsky et al. (2013), Gumi et al. (2012), Moda et al. (1996) \\
\hline Anthrax & Bacteria & 3 & Aikembayev et al. (2010), Musa et al. (1993), Woods et al. (2004) \\
\hline Trypanosoma evansi & Parasite & 2 & Bennoune et al. (2013), Haridy et al. (2011) \\
\hline Ecthyma & Virus & 2 & Bazargani et al. (2010), Moallin and Zessin (1988) \\
\hline Rotavirus & Virus & 2 & Ghosh et al. (2011), Jere et al. (2014) \\
\hline Helminth & Parasite & 2 & Anvari-Tafti et al. (2013), McCarthy and Moore (2000) \\
\hline Toxoplasmosis & Parasite & 2 & Alanazi (2013), Dehkordi et al. (2013) \\
\hline $\begin{array}{l}\text { Alkhurma hemor- } \\
\text { rhagic fever }\end{array}$ & Virus & 1 & Carletti (2010) \\
\hline $\begin{array}{c}\text { Betacoronavirus } \\
\text { UAE-HKU23 }\end{array}$ & Virus & 1 & Woo et al. (2014) \\
\hline $\begin{array}{l}\text { Dera Ghazi Khan } \\
\text { virus }\end{array}$ & Virus & 1 & Walker et al. (2016) \\
\hline HCoV-229E & Virus & 1 & Corman et al. (2018) \\
\hline
\end{tabular}


Table 1. continued

\begin{tabular}{llll}
\hline Disease/agent & Type & Paper count & References \\
\hline Rabies & Virus & 1 & Bloch and Diallo (1995) \\
Torque teno virus & Virus & 1 & Al-Moslih et al. (2007) \\
Aeromonas spp. & Bacteria & 1 & Ghenghesh et al. (2001) \\
Bartonella & Bacteria & 1 & Rasis et al. (2014) \\
Glanders (Burkholderia mallei) & Bacteria & 1 & Scholz et al. (2014) \\
Johne's disease (paratuberculosis) & Bacteria & 1 & Ghosh et al. (2012) \\
Klebsiella pneumoniae & Bacteria & 1 & Sharma et al. (2013a) \\
Rickettsia aeschlimannii & Bacteria & 1 & Kleinerman et al. (2013) \\
Babesia bovis & Parasite & 1 & Ereqat et al. (2016) \\
Cryptosporidium & Parasite & 1 & Sazmand et al. (2012) \\
Fascioliasis & Parasite & 1 & Younan et al. (2016) \\
Leishmaniosis & Parasite & 1 & Ashford (2000) \\
Onchocerciasis & Parasite & 1 & El-Bahnasawy et al. (2015) \\
Sarcocystis & Parasite & 1 & Chhabra and Samantaray (2012) \\
Trichinellosis & Parasite & 1 & Bommer et al. (1980)
\end{tabular}

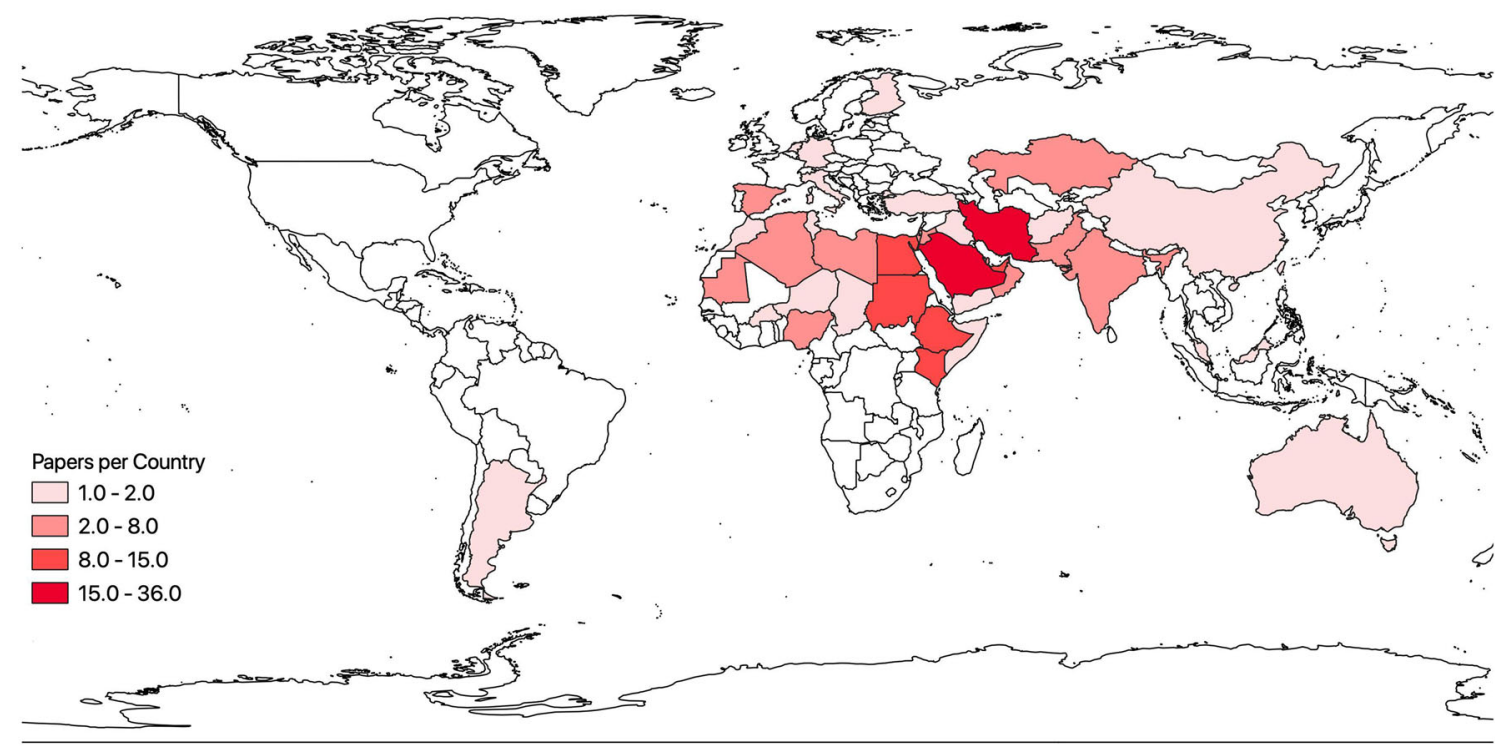

Figure 3. Number of publications by country of study, range $n=1$ Finland, Argentina to $n=36$ Saudi Arabia

\section{Viral}

The large majority of publications were related to MERS $n=118$, a novel coronavirus. Genetic comparisons between camel and human isolated MERS are highly similar and camels continue to exhibit positive seropositivity for MERS in recent tests (Chu et al. 2018).

The review identified 19 papers on Rift Valley fever (RVF) transmission, most of which detailed how common seropositivity to RVF virus was in camel herds. Four of these papers emphasized that livestock like camels, cattle, and sheep served as important amplifiers for the virus, especially prior to outbreaks in Kenya and Mauritania (Bird et al. 2008; Britch et al. 2013; El Mamy et al. 2011, 2014).

Four of nine publications on Camelpox discussed human transmission, including a paper that reported the first laboratory-confirmed case of human Camelpox (Bera et al. 2011). 


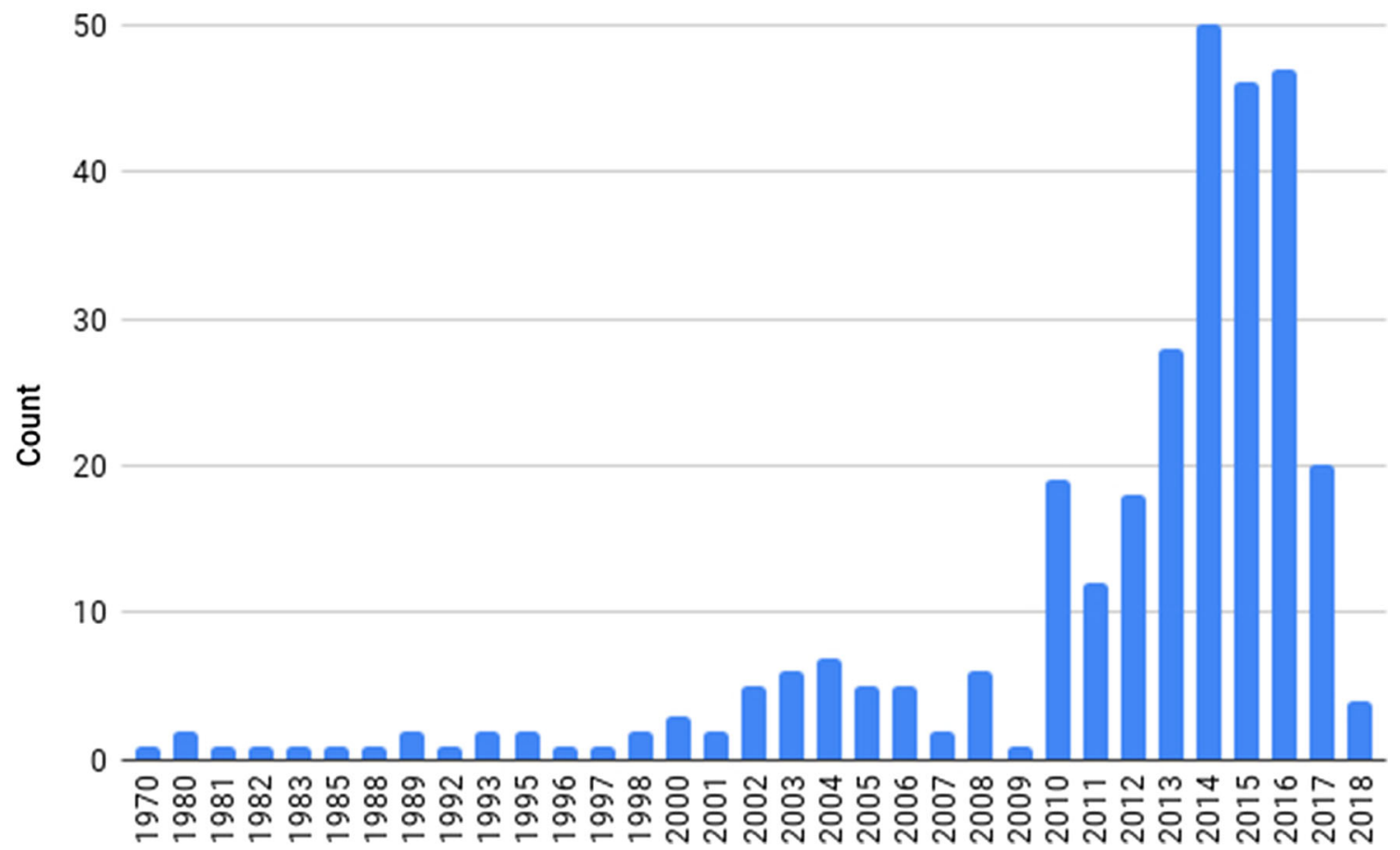

Fig. 4. Frequency of camel-borne disease publications between 1970 and 2018 identified in this review

There were five papers on hepatitis $\mathrm{E}$, one of the five known human hepatitis virus strains, in which camel meat and milk were implicated as risk factors in humans through whole-genome sequencing, HEV IgM, or HEV RNA detection (Pavio et al. 2015 Khuroo and Khuroo 2016; Lee et al. 2016; Rasche et al. 2016; Spahr et al. 2018). In one of these reports, a liver transplant patient in the United Arab Emirates consumed camel meat and milk regularly and was chronically infected with hepatitis E (Lee et al. 2016).

While no publication documented clinical evidence of camel-human rabies transmission, one paper presented probable evidence of camel-to-human rabies transmission (Bloch and Diallo 1995).

A 2018 publication noted that $\mathrm{HCoV}-229 \mathrm{E}$, a primarily non-lethal coronavirus responsible for a proportion of upper and lower respiratory tract infections, can be transmitted from camels to humans similar to MERS transmission, thus implicating dromedary camels as a possible reservoir of coronaviruses (Corman et al. 2018). Woo et al. (2014) identified a novel betacoronavirus UAE-HKU23 or dromedary camel coronavirus DcCOV in the United Arab Emirates that was detected in $52 \%$ of tested camel serum samples.

Other viruses that were found in camels include Alkhurma hemorrhagic fever (AHF) virus $n=1$, CrimeanCongo hemorrhagic fever (CCHF) virus $n=4$, rotavirus $n=2$, camel contagious ecthyma $n=2$, torque teno virus $n=1$, and Dera Ghazi Khan virus $n=1$ (Moallin and Zessin 1988; Khan et al. 1997; Al-Moslih et al. 2007; Bazargani et al. 2010; Carletti 2010; Ghosh et al. 2011; Horton et al. 2014; Jere et al. 2014; Champour et al. 2016; Walker et al. 2016).

\section{Bacterial}

A total of 35 papers discussed the risk of brucellosis as a public health threat from camels. Most of these 35 papers (18; 51\%) were seroprevalence studies of brucellosis in camels, which reported a prevalence range of between 1.4 and 37.5\% (Schelling et al. 2004; Omer et al. 2010a, b).

Bacterial diseases that are transmitted through food, water, or other types of fecal-oral transmission were grouped together as "food-borne." This group included Salmonella, E. coli, Helicobacter, Staphylococcus, Enterococci, Campylobacter, and Leptospirosis. These diarrheal bacteria were reported in 15 papers, four of which discussed testing for antimicrobial resistance in camels and camel products (Rahimi et al. 2010; Tadesse 2015; Tejedor-Junco et al. 2015; Fadlelmula et al. 2016).

Ten papers described camel transmission of plague, Yersinia pestis. In fact, three papers documented plague infection in patients who directly consumed raw camel 
meat (Christie et al. 1980; Arbaji et al. 2005; Cabanel et al. 2013).

Seven papers detailed high Q fever Coxiella burnetii seropositivity in camels (Schelling et al. 2003; Schelling et al. 2004; Vanderburg et al. 2014; Pirouz et al. 2015; Njeru et al. 2016; Mohabbati Mobarez et al. 2017; Klemmer et al. 2018). Seroprevalence levels of up to $73 \%$ were present in camels in Chad (Schelling et al. 2004). Humans that work in close contact with camels such as herders, farmers, and breeders are especially at risk of $\mathrm{Q}$ fever transmission, with one study finding a high odds ratio $(\mathrm{OR}=9)$ for the association of being a camel breeder and $\mathrm{Q}$ fever seropositivity (Schelling et al. 2003).

The four papers on camel tuberculosis all discussed positive detection of $M$. bovis, indicating that camels are likely also a reservoir for human transmission (Cosivi et al. 1995; Moda et al. 1996; Gumi et al. 2012; GarineWichatitsky et al. 2013). Gumi et al. (2012) found isolated M. tuberculosis from camels and M. bovis from humans, which suggests cross-species transmission of both strains of bacteria.

One of three papers on anthrax conclusively extracted anthrax spores from infected camel meat, which led to illness in ten people (Musa et al. 1993).

Other bacterial diseases in the literature but occurring less frequently included Rickettsia aeschlimannii 1, Klebsiella pneumoniae 1, Aeromonas spp. 1, Bartonella spp. 1, Burkholderia mallei 1, and M. avium subsp. paratuberculosis 1 (Ghenghesh et al. 2001; Ghosh et al. 2012; Kleinerman et al. 2013; Sharma et al. 2013a, b; Rasis et al. 2014; Scholz et al. 2014).

\section{Parasitic}

The most common zoonotic parasite transmitted from camels to humans was Echinococcus granulosus $n=46$. This parasite has a variety of hosts but is often found in livestock as intermediate hosts, including camels. A review by Alvarez Rojas et al. (2014) estimated that the camel strain of E. granulosus causes between 7 and $11 \%$ of all hydatid infections in humans. This attributable risk estimate likely varies by geographic location; a molecular survey by Omar et al. $(2010 \mathrm{a}, \mathrm{b})$ found that $59 \%$ of camels in Sudan were infected with E. granulosus, and a subsequent Sudanese paper found that camels and cattle were the principal intermediate host, not sheep as previously believed (Elmahdi et al. 2004).
There were two papers on the parasite Trypanosoma evansi. Prevalence rates of up to $14 \%$ were found in camels in Algeria which is comparatively high to other countries and increases risk for human transmission (Bennoune et al. 2013). Human cases, confirmed with ELISA and stained blood films, of T. evansi have been reported in India and Egypt (Haridy et al. 2011).

Parasitic diseases are commonly passed from camels to humans through meat and milk consumption. One paper on a trichinellosis outbreak in Germany detailed how camel meat brought from Egypt was responsible for zoonotic transmission (Bommer et al. 1980), and in 2013, researchers detected Toxoplasma gondii in camel milk (Dehkordi et al. 2013). Other fecal- and meat-/milktransmitted parasites included Leishmania spp. $n=1, B a$ besia bovis $n=1$, Cryptosporidium spp. $n=1$, and Sarcocystis spp. $n=1$ (Ashford 2000; Sazmand et al. 2012; Chhabra and Samantaray 2012; Ereqat et al. 2016). Four other parasite species found in this cohort were helminths Haemonchus tataricus, Trichostrongylus hamatus, and Trichuris infundibulus $n=2$; Linguatula serrata $n=7$; Onchocerca volvulus $n=1$; and Fasciola hepatica or Fasciola gigantica $n=1$ (Sadjjadi et al. 1998; McCarthy and Moore 2000; Shakerian et al. 2008; Haddadzadeh et al. 2010; Oryan et al. 2011; Rezaei et al. 2012; Anvari-Tafti et al. 2013; Bamorovat et al. 2014; Youssef and Uga 2014; El-Bahnasawy et al. 2015; Farjanikish and Shokrani 2016).

\section{Discussion}

As determined by publication count as well as known mortality rates, viruses in this review are of highest interest, followed by bacteria and parasites (Table 1). Camels are as ubiquitous as cattle or sheep in many parts of the world; yet, knowledge on potential health risks lags behind that of other livestock species. The combination of human-related climate change, population growth, decline in biodiversity, and land-use change are major drivers for the evolution and spread of zoonotic disease (Engering et al. 2013).

The emergence of MERS, with outbreaks between 2012 and 2016, was an outcome of these realities, and it is no surprise that MERS continues to receive high amounts of publicity and funding due to its high human fatality rates $\sim 35 \%$ and pandemic potential (World Health Organization 2017). There are currently no widely used vaccines against MERS, but knowledge of its transmission is critical to better implement food safety and sanitation practices 
within the camel value chain. Rift Valley fever (RVF) was the second most common camel-borne zoonosis in this review and is not a significant source of mortality as less than $3 \%$ of patients develop lethal symptoms. However, it is a significant cause of morbidity especially in high-risk populations such as veterinarians, butchers, scientists, animal health workers, farmers, and herders (Ikegami and Makino 2011). The same goes for Camelpox, which is a minor health problem for camel farmers but incurs significant economic damages from the death of young camels, reduced milk yield, and lasting morbidity (Balamurugan et al. 2013). MERS, RVF, and Camelpox were some of the most commonly reported camel-borne zoonotic viruses in this literature review, but for preventive purposes awareness of the following viruses is important to promote. Crimean-Congo hemorrhagic fever is listed as a disease with epidemic potential due to its high mortality rate, growing prevalence in Asia and Europe, and lack of vaccines (Mertens et al. 2013). Alkhurma hemorrhagic fever (AHF) is also a disease of interest because of its hemorrhagic symptoms, recent emergence, and lack of detailed knowledge of its symptoms and transmission. Mortality rates for these viruses along with other hemorrhagic fevers are high because of difficulties in disease diagnosis (World Health Organization 2016). Alkhurma hemorrhagic fever, CCHF, and Dera Ghazi Khan are mosquito- and tick-borne diseases where camels act as reservoirs and amplifiers (Carletti 2010; Walker et al. 2016). Thus, vector surveillance and management around camels in addition to the aforementioned sanitation practices could be highly beneficial to control the spread of these diseases.

The bacterial disease of greatest concern is brucellosis, which is not only zoonotic but also causes severe economic losses for farmers and ranchers across the world in lost milk, reduced fertility, stillbirths, and abortions (Akakpo et al. 2010). Camel farmers should be cautious and aware when handling camels, and this exemplifies another area where increased attention to sanitation practices would be beneficial. Food-borne diseases are of high importance as evidenced by the rapid establishment of complex camel milk value chains in urban Kenya as well as the breadth of food-borne pathogens found in our review (Muloi et al. 2018). These locations exemplify the high-risk transmission interfaces that are formed due to a lack of proper protocol and oversight by government agencies in regard to food safety training and hygienic practices (Muloi et al. 2018). Camels contract plague from infected fleas and may infect humans through contact with infected bodily fluids or consumption of infected meat (Leslie et al. 2011). However, vaccination in humans can be used to control the spread and occurrence of outbreaks. For example, vaccination rates have steadily increased in Kazakhstan since 2001 and the usage of vaccines in combination with antibiotics has greatly reduced case fatality across the country (Aikimbajev et al. 2003). The abundance of publications on brucellosis, plague, and food-borne bacterial illnesses reaffirms their presence in camels.

The earliest papers in this review came from the 1970s and almost exclusively discussed parasites like E. granulosus with occasional papers on viral and bacterial disease. This finding is consistent with a historical lack of widespread high-quality technology for viral and bacterial detection, as well as increased focus on viruses today as compared to 30 40 years ago. Parasitic diseases in this review were not significant sources of mortality. Cysts from E. granulosus occur on lung and liver tissue along with other internal organs and contribute to morbidity in humans through pressure effects and problematic locations of cysts (Mandal and Deb Mandal 2012). Vaccination of camels against $E$. granulosus is not widely practiced because sheep and dogs are considered to be more important hosts: This, in combination with unsanitary practices and high camel and sheep densities, creates higher risk for humans in these areas (Zhang and McManus 2006). No other publications on parasites showed that they were significant sources of human mortality, and there were low paper counts for most parasites, which could indicate their rarity in camels and largely non-lethal status.

Many studies demonstrated a high seroprevalence to a variety of zoonotic pathogens in camel populations along with current or past examples of camel-human transmission. However, few validated standardized tests exist for camels, making disease detection and confirmation difficult (Gwida et al. 2011). Seropositivity is an indication of antibodies and not antigens, so while this shows that a camel was exposed, it does not provide information on the infection status of the individual or the ability of the camel to transmit a pathogen. These papers may not have exact confirmation for each strain in each country or population, but high prevalence coupled with known instances of transmission provides a guideline for prospective risks. Additionally, because we did not analyze our results with statistical methods we were unable to assess the strength of association between pathogens and human risk. Another limitation of our review was the absence of certain pivotal papers; this may have been due to the use of Google Scholar 
as one of the two major search engines. A serosurvey of $\mathrm{Q}$ fever in Laikipia County, Kenya, that revealed high seroprevalence $18.6 \%$ in dromedaries was one such paper that fit our inclusion and search criteria keywords: camel, zoonotic, human, but did not appear in any searches (Browne et al. 2017). A common critique of Google Scholar is the limited ability to sort results, which thus provides evidence that it misses important literature in many case studies (Haddaway et al. 2015). Although we did use PubMed we still may have missed eligible publications because of relevance sorting and/or using only the first 100 results. Our study was limited to peer-reviewed material in English and excludes a thorough review of French, Turkish, Farsi, and Arabic literature which could have provided more information in target regions. The use of additional search engines or search terms may improve the scope of literature reviews, which we will make note of for the future.

Lastly, a limitation not necessary related to methodology but rather the epidemiology of diseases relates to missing diseases at the camel-other livestock/wildlife-human interface that we would not have captured in our review. Although we did not include them as part of this review there were papers found in our initial searches that described camel-livestock and camel-wildlife transmission. These shared pathogens may be zoonotic and include camels as part of the transmission cycle but are not necessarily identified as a camel-borne zoonosis. For example, other animals may be the original or primary source of many pathogens, such as the case of MERS in bats, with the camel being an intermediate host in the transmission from animal to human (Corman et al. 2014a, b).

Dromedary camels are a staple in the diets and lives of humans like their cattle and pig counterparts, but research on their zoonotic disease potential is lacking in comparison. When the map of camel population density is compared to the geographic site of published papers found in this review, we see that the two have high levels of intersection in Africa, Asia, and the Middle East (Figures 1 and 3). However, these maps also show that in many instances camel-borne zoonoses are not restricted to areas of high camel numbers and human infections can and do occur in countries with very low camel populations, and even in countries with no camels as a person may be exposed in one region and travel to another. Therefore, veterinarians, farmers, and others working in close contact with camels and camel products should be cognizant of these potential pathogens, not just in areas where camels are raised but also where camel products may be processed and transported. Additionally, physicians must be aware of where their patients have traveled. Knowledge of potential camelborne diseases is thus important for researchers and health workers to consider globally.

\section{CONCLUSION}

Camels are not common outside of hot and arid areas such as sub-Saharan Africa or the Middle East, but knowledge of their potential carrier status is important to researchers, zoo personnel, and travelers. The MERS and Ebola outbreaks in recent years have shown how rapidly pathogens can travel and erupt in novel human populations; population expansion and a lack of extensive healthcare systems make camel-endemic areas a potential hot spot for zoonotic spillover. Many of the zoonotic pathogens of camels are a current or possible future risk to human health and must be considered by medical professionals, especially in light of the increased use of camels as a growing protein source globally. As we collect epidemiologic data on the routes of transmission and sources of these infectious agents, we become better prepared to manage and mitigate their impact on humans. Camel milk and meat act as a point source for infection and should be managed with proper slaughter protocols, pasteurization, and improved overall sanitation practices. Dromedary camels also act as a significant source and amplifier for vector-borne disease; therefore, vaccination of camels, control of mosquitoes and ticks, insecticide application, and consistent screening will help control infection rates in camels and humans. In this literature review, we highlight a number of camel-borne zoonotic diseases. The number of pathogens and spillover events will most likely continue to grow as human and camel populations increase and increasingly intersect.

\section{ACKNOWLEDGEMENTS}

This work was made possible by the generous support of the American people through the United States Agency for International Development (USAID) Emerging Pandemic Threats PREDICT Cooperative Agreement No. AID-OAAA-14-00102. The contents are the responsibility of the authors and do not necessarily reflect the views or the policy of USAID or the US Government, and no official endorsement should be inferred. Thank you to Smithsonian Conservation Biology Institute and Saint Louis Zoo 
Institute for Conservation Medicine for additional funding to complete this research. Special thanks to our fellow camel researchers and their contributions over the years.

\section{Compliance with Ethical Standards}

CONFLICT OF INTEREST The authors declare that they have no conflict of interest.

\section{REFERENCES}

Abbas B, Agab H (2002) A review of camel brucellosis. Prev Vet Med 55:47-56. https://doi.org/10.1016/S0167-58770200055-7

Abdel Aaty HE, Abdel-Hameed DM, Alam-Eldin YH, El-Shennawy SF, Aminou HA, Makled SS, Darweesh SK (2012) Molecular genotyping of Echinococcus granulosus in animal and human isolates from Egypt. Acta Trop 121:125-128. https:// doi.org/10.1016/j.actatropica.2011.10.014

Abdo-Salem S, Gerbier G, Bonnet P, Al-Qadasi M, Tran A, Thiry E, Al-Eryni G, Roger F (2006) Descriptive and spatial epidemiology of Rift Valley fever outbreak in Yemen 2000-2001. Ann N Y Acad Sci 1081:240-242. https://doi.org/10.1196/annals. 1373.028

Abushhewa MH, Abushhiwa MHS, Nolan MJ, Jex AR, Campbell BE, Jabbar A, Gasser RB (2010) Genetic classification of Echinococcus granulosus cysts from humans, cattle and camels in Libya using mutation scanning-based analysis of mitochondrial loci. Mol Cell Probes 24:346-351. https://doi.org/10.1016/ j.mcp.2010.07.005

Adney DR, van Doremalen N, Brown VR, Bushmaker T, Scott D, de Wit E, Bowen RA, Munster VJ (2014) Replication and Shedding of MERS-CoV in upper respiratory tract of inoculated dromedary camels. Emerg Infect Dis 20:1999-2005. https:// doi.org/10.3201/eid2012.141280

Ahmadi NA (2005) Hydatidosis in camels Camelus dromedarius and their potential role in the epidemiology of Echinococcus granulosus in Iran. J Helminthol 79:119-125. https://doi.org/ 10.1079/JOH2005279

Ahmed AE (2017) Diagnostic delays in 537 symptomatic cases of Middle East respiratory syndrome coronavirus infection in Saudi Arabia. Int J Infect Dis 62:47-51. https://doi.org/10.1016/ j.ijid.2017.07.008

Ahmed AE (2017) The predictors of 3- and 30-day mortality in 660 MERS-CoV patients. BMC Infect Dis. https://doi.org/ $10.1186 / \mathrm{s} 12879-017-2712-2$

Ahmed Kamal S (2011) Observations on Rift Valley fever virus and vaccines in Egypt. Virol J 8:532. https://doi.org/10.1186/ 1743-422X-8-532

Ahmed MO, Elmeshri SE, Abuzweda AR, Blauo M, Abouzeed YM, Ibrahim A, Salem H, Alzwam F, Abid S, Elfahem A, Elrais A (2010) Seroprevalence of brucellosis in animals and human populations in the western mountains region in Libya, December 2006-January 2008. Euro Surveill 15:30

Aikembayev AM, Lukhnova L, Temiraliyeva G, Meka-Mechenko T, Pazylov Y, Zakaryan S, Denissov G, Easterday WR, Van Ert MN, Keim P, Francesconi SC, Blackburn JK, Hugh-Jones M, Hadfield T (2010) Historical Distribution and Molecular
Diversity of Bacillus anthracis, Kazakhstan. Emerg Infect Dis 16:789-796. https://doi.org/10.3201/eid1605.091427

Aikimbajev A, Meka-Mechenko T, Temiralieva G, Bekenov J, Sagiyev Z, Kaljan K, Mukhambetova AK (2003) Plague in Kazakhstan at the present time. Przegl Epidemiol 57:593-598

Akakpo A, Têko-Agbo A, Koné P 2010 The impact of brucellosis on the economy and public health in Africa. In: Compendium of technical items presented to the OIE World Assembly of Delegates or to OIE Regional Commissions, vol 2009, pp 71-84.

Al Dahouk S, Sprague LD, Neubauer H (2013) New developments in the diagnostic procedures for zoonotic brucellosis in humans. Revue Scientifique Et Technique International Office of Epizootics 32:177-188

Al Hammadi ZM, Chu DKW, Eltahir YM, Al Hosani F, Al Mulla M, Tarnini W, Hall AJ, Perera RAPM, Abdelkhalek MM, Peiris JSM, Al Muhairi SS, Poon LLM (2015) Asymptomatic MERS$\mathrm{CoV}$ infection in humans possibly linked to infected dromedaries imported from Oman to United Arab Emirates, May 2015. Emerg Infect Dis 21:2197-2200. https://doi.org/10.3201/eid2 112.151132

Al-Moslih MI, Perkins H, Hu Y-W (2007) Genetic relationship of Torque Teno virus TTV between humans and camels in United Arab Emirates UAE. J Med Virol 79:188-191. https://doi.org/ 10.1002/jmv.20776

Al salihi SF, Alrodhan M (2017) Phylogenetic analysis of MERS$\mathrm{CoV}$ in human and camels in Iraq. Int J Pharm Res Allied Sci 6:120-129

Al-Tawfiq J, Memish ZA (2014) Middle East respiratory syndrome coronavirus: epidemiology and disease control measures. Infect Drug Resist. https://doi.org/10.2147/idr.s51283

Al-Tawfiq J, Memish ZA (2014) Middle East respiratory syndrome coronavirus: transmission and phylogenetic evolution. Trends Microbiol 22:573-579. https://doi.org/10.1016/j.tim.2014.08.001

Al-Tawfiq J, Zumla A, Memish ZA (2014) Travel implications of emerging coronaviruses: SARS and MERS-CoV. Travel Med Infect Disease 12:422-428. https://doi.org/10.1016/j.tmaid. 2014.06.007

Alagaili AN, Briese T, Mishra N, Kapoor V, Sameroff SC, de Wit E, Munster VJ, Hensley LE, Zalmout IS, Kapoor A, Epstein JH, Karesh WB, Daszak P, Mohammed OB, Lipkin WI (2014) Middle East respiratory syndrome coronavirus infection in dromedary camels in Saudi Arabia. mBio. https://doi.org/ 10.1128/mbio.00884-14

Alanazi AD (2013) Determination of Seropositivity for Toxoplasma Gondii in Sheep, Goats and Camels Slaughtered for Food and Human Consumptions in Riyadh Municipal Abattoirs, Saudi Arabia. J Egypt Soc Parasitol 43:569-576. https://doi.org/ 10.12816/0006414

Aleanizy FS, Mohmed N, Alqahtani FY, El Hadi Mohamed RA (2017) Outbreak of Middle East respiratory syndrome coronavirus in Saudi Arabia: a retrospective study. BMC Infect Dis. https://doi.org/10.1186/s12879-016-2137-3

Alexandersen S, Kobinger GP, Soule G, Wernery U (2014) Middle East respiratory syndrome coronavirus antibody reactors among camels in Dubai, United Arab Emirates, in 2005. Transbound Emerg Disease 61:105-108. https://doi.org/10.1111/tbed.12212

Alhakeem RF, Midgley CM, Assiri AM, Alessa M, Al Hawaj H, Saeed AB, Almasri MM, Lu X, Abedi GR, Abdalla O, Mohammed M, Algarni HS, Al-Abdely HM, Alsharef AA, Nooh R, Erdman DD, Gerber SI, Watson JT (2016) Exposures among MERS Case-Patients, Saudi Arabia, January-February 2016. 
Emerg Infect Dis 22:2020-2022. https://doi.org/10.3201/ eid2211.161042

Alhamlan FS, Majumder MS, Brownstein JS, Hawkins J, Al-Abdely HM, Alzahrani A, Obaid DA, Al-Ahdal MN, BinSaeed A (2017) Case characteristics among Middle East respiratory syndrome coronavirus outbreak and non-outbreak cases in Saudi Arabia from 2012 to 2015. BMJ Open 7:e011865. https:// doi.org/10.1136/bmjopen-2016-011865

Ali MA, Shehata MM, Gomaa MR, Kandeil A, El-Shesheny R, Kayed AS, El-Taweel AN, Atea M, Hassan N, Bagato O, Moatasim Y, Mahmoud SH, Kutkat O, Maatouq AM, Osman A, McKenzie PP, Webby RJ, Kayali G (2017) Systematic, active surveillance for Middle East respiratory syndrome coronavirus in camels in Egypt. Emerg Microbes Infect 6:e1-e1. https:// doi.org/10.1038/emi.2016.130

Alraddadi BM, Watson JT, Almarashi A, Abedi GR, Turkistani A, Sadran M, Housa A, Almazroa MA, Alraihan N, Banjar A, Albalawi E, Alhindi H, Choudhry AJ, Meiman JG, Paczkowski M, Curns A, Mounts A, Feikin DR, Marano N, Swerdlow DL, Gerber SI, Hajjeh R, Madani TA (2016) Risk Factors for primary Middle East respiratory syndrome coronavirus illness in humans, Saudi Arabia, 2014. Emerg Infect Dis 22:49-55. https:// doi.org/10.3201/eid2201.151340

Alsolamy S, Yousif S, Alotabi B, Aljerian N, Alrajhi K, Al Somali S, Alsaawi A (2017) Middle East respiratory syndrome: global outbreak data analysis. J Anc Dis Prev Remedies. https://doi.org/ 10.4172/2329-8731.1000159

Alvarez Rojas CA, Romig T, Lightowlers MW (2014) Echinococcus granulosus sensu lato genotypes infecting humans - review of current knowledge. Int J Parasitol 44:9-18. https://doi.org/ 10.1016/j.ijpara.2013.08.008

Anvari-Tafti M, Sazmand A, Hekmatimoghaddam S, Moobedi I (2013) Gastrointestinal helminths of camels Camelus dromedarius in center of Iran. Trop Biomed 30:56-61

Arbaji A, Kharabsheh S, Al-Azab S, Al-Kayed M, Amr ZS, Abu Baker M, Chu MC (2005) A 12-case outbreak of pharyngeal plague following the consumption of camel meat, in northeastern Jordan. Ann Trop Med Parasitol 99:789-793. https:// doi.org/10.1179/136485905X65161

Ashford R (2000) The leishmaniases as emerging and reemerging zoonoses. Int J Parasitol 30:1269-1281. https://doi.org/10.1016/ S0020-75190000136-3

Assiri AM, Midgley CM, Abedi GR, Bin Saeed A, Almasri MM, Lu X, Al-Abdely HM, Abdalla O, Mohammed M, Algarni HS, Alhakeem RF, Sakthivel SK, Nooh R, Alshayab Z, Alessa M, Srinivasamoorthy G, AlQahtani SY, Kheyami A, HajOmar WH, Banaser TM, Esmaeel A, Hall AJ, Curns AT, Tamin A, Alsharef AA, Erdman D, Watson JT, Gerber SI (2016) Epidemiology of a novel recombinant Middle East respiratory syndrome coronavirus in humans in Saudi Arabia. J Infect Dis 214:712-721. https://doi.org/10.1093/infdis/jiw236

Azab ME, Bishara SA, Helmy H, Oteifa NM, El-Hoseiny LM, Ramzy RMR, Ahmed MA (2004) Molecular characterization of Egyptian human and animal Echinococcus granulosus isolates by RAPD-PCR technique. J Egypt Soc Parasitol 34:83-96

Azhar EI, El-Kafrawy SA, Farraj SA, Hassan AM, Al-Saeed MS, Hashem AM, Madani TA (2014) Evidence for Camel-to-Human Transmission of MERS Coronavirus. $N$ Engl J Med 370:2499-2505. https://doi.org/10.1056/NEJMoa1401505

Azhar EI, Hashem AM, El-Kafrawy SA, Sohrab SS, Aburizaiza AS, Farraj SA, Hassan AM, Al-Saeed MS, Jamjoom GA, Madani TA (2014) Detection of the Middle East respiratory syndrome coronavirus genome in an air sample originating from a camel barn owned by an infected patient. mBio. https://doi.org/ 10.1128/mbio.01450-14

Babelhadj B, Di Bari MA, Pirisinu L, Chiappini B, Gaouar SBS, Riccardi G, Marcon S, Agrimi U, Nonno R, Vaccari G (2018) Prion disease in dromedary camels, Algeria. Emerg Infect Dis 24:1029-1036. https://doi.org/10.3201/eid2406.172007

Balamurugan V, Venkatesan G, Bhanuprakash V, Singh RK (2013) Camelpox, an emerging orthopox viral disease. Indian J Virol 24:295-305. https://doi.org/10.1007/s13337-013-0145-0

Balkhy HH, Alenazi TH, Alshamrani MM, Baffoe-Bonnie H, AlAbdely HM, El-Saed A, Al Arbash HA, Al Mayahi ZK, Assiri AM, Bin Saeed A (2016) Notes from the field: nosocomial outbreak of Middle East respiratory syndrome in a large tertiary care hospital-Riyadh, Saudi Arabia, 2015. MMWR Morb Mortal Wkly Rep 65:163-164. https://doi.org/10.15585/ mmwr.mm6506a5

Bamorovat M, Zarandi MB, Mostafavi M, Kheirandish R, Sharifi I, Radfar MH (2014) The prevalence of Linguatula serrata nymphs in mesenteric and mediastinal lymph nodes in onehumped camels Camelus dromedarius slaughtered in Rafsanjan slaughterhouse, Iran. J Parasit Dis 38:374-377. https://doi.org/ 10.1007/s12639-013-0258-9

Banik GR, Khandaker G, Rashid H (2015) Middle East respiratory syndrome coronavirus "MERS-CoV": current knowledge gaps. Paediatr Respir Rev 16:197-202. https://doi.org/10.1016/ j.prrv.2015.04.002

Bardonnet K, Benchikh-Elfegoun M, Bart J, Harraga S, Hannache N, Haddad S, Dumon H, Vuitton D, Piarroux R (2003) Cystic echinococcosis in Algeria: cattle act as reservoirs of a sheep strain and may contribute to human contamination. Vet Parasitol 116:35-44. https://doi.org/10.1016/S0304-40170300255-3

Bardonnet K, Piarroux R, Dia L, Schneegans F, Beurdeley A, Godot V, Vuitton DA (2002) Combined eco-epidemiological and molecular biology approaches to assess Echinococcus granulosus transmission to humans in Mauritania: occurrence of the 'camel' strain and human cystic echinococcosis. Trans $R$ Soc Trop Med Hyg 96:383-386. https://doi.org/10.1016/S003592030290369-X

Bazargani TT, Nikjou D, Tafty A, Varshovi HR, Niasari-Naslaji A (2010) A regional outbreak of contagious camel echtyma in Iran. J Camel Pract Res 17:221-224

Bekele W, Tessema T, Melaku S (2013) Camelus dromedarius brucellosis and its public health associated risks in the Afar National Regional State in northeastern Ethiopia. Acta Vet Scand 55:89. https://doi.org/10.1186/1751-0147-55-89

Bennoune O, Adili N, Amri K, Bennecib L, Ayachi A (2013) Trypanosomiasis of camels Camelus dromedarius in Algeria: first report. Vet Res Forum 4:273-275

Bera BC, Barua S, Shanmugasundaram K, Anand T, Riyesh T, Vaid RK, Virmani N, Kundu S, Yadav NK, Malik P, Singh RK (2015) Genetic characterization and phylogenetic analysis of host-range genes of Camelpox virus isolates from India. Virus Disease 26:151-162. https://doi.org/10.1007/s13337-015-0266-8

Bera BC, Shanmugasundaram K, Barua S, Gupta A, Riyesh T, et al. (2010) IBT/033 sequence analysis of Schlafen gene of Camelpox virus CMLV isolated from recent outbreak 2009 in Rajasthan. $J$ Immunol Immunopathol 12:2

Bera BC, Shanmugasundaram K, Barua S, Venkatesan G, Virmani N, Riyesh T, Gulati BR, Bhanuprakash V, Vaid RK, Kakker NK, Malik P, Bansal M, Gadvi S, Singh RV, Yadav V, Sardarilal Nagarajan G, Balamurugan V, Hosamani M, Pathak KML, Singh RK (2011) Zoonotic cases of camelpox infection in India. 
Vet Microbiol 152:29-38. https://doi.org/10.1016/j.vetmic.2011.04.010

Bird BH, Githinji JWK, Macharia JM, Kasiiti JL, Muriithi RM, Gacheru SG, Musaa JO, Towner JS, Reeder SA, Oliver JB, Stevens TL, Erickson BR, Morgan LT, Khristova ML, Hartman AL, Comer JA, Rollin PE, Ksiazek TG, Nichol ST (2008) Multiple virus lineages sharing recent common ancestry were associated with a large Rift Valley fever outbreak among Livestock in Kenya during 2006-2007. J Virol 82:11152-11166. https:// doi.org/10.1128/JVI.01519-08

Bloch N, Diallo I (1995) A probable outbreak of rabies in a group of camels in Niger. Vet Microbiol 46:281-283. https://doi.org/ 10.1016/0378-11359500092-O

Bommer W, Kaiser H, Mergerian H, Pottkämper G 1980 Outbreak of trichinelliasis in a youth centre in Neidersachsen by airdried imported camel meat. In: Proceedings of the 1st world congress on foodborne infections and intoxications, 29 June-3 July 1980, West Berlin, Germany, vol 1, pp 441-444

Bramanti B, Stenseth NC, Walløe L, Lei X (2016) Plague: a disease which changed the path of human civilization. Dordrecht: Springer, pp 1-26

Britch SC, Binepal YS, Ruder MG, Kariithi HM, Linthicum KJ, Anyamba A, Small JL, Tucker CJ, Ateya LO, Oriko AA, Gacheru S, Wilson WC (2013) Rift Valley fever risk map model and seroprevalence in selected wild ungulates and camels from Kenya. PLoS ONE 8:e66626. https://doi.org/10.1371/journal.pone. 0066626

Browne AS, Fèvre EM, Kinnaird M, Muloi DM, Wang CA, Larsen PS, O'Brien T, Deem SL (2017) Serosurvey of Coxiella burnetii $\mathrm{Q}$ fever in dromedary camels Camelus dromedarius in Laikipia County, Kenya. Zoonoses Public Health 64:543-549. https://doi.org/10.1111/zph.12337

Buchholz U, Müller MA, Nitsche A, Sanewski A, Wevering N, Bauer-Balci T, Bonin F, Drosten C, Schweiger B, Wolff T, Muth D, Meyer B, Buda S, Krause G, Schaade L, Haas W 2013 Contact investigation of a case of human novel coronavirus infection treated in a German hospital, October-November 2012. Euro Surveillance 18

Cabanel N, Leclercq A, Chenal-Francisque V, Annajar B, Rajerison M, Bekkhoucha S, Bertherat E, Carniel E (2013) Plague Outbreak in Libya, 2009, Unrelated to Plague in Algeria. Emerg Infect Dis 19:230-236. https://doi.org/10.3201/eid1902.121031

Carletti F (2010) Alkhurma hemorrhagic fever in travelers returning from Egypt, 2010. Emerg Infect Dis. https://doi.org/ 10.3201/eid1612101092

Casulli A, Zeyhle E, Brunetti E, Pozio E, Meroni V, Genco F, Filice C (2010) Molecular evidence of the camel strain G6 genotype of Echinococcus granulosus in humans from Turkana, Kenya. Trans $R$ Soc Trop Med Hyg 104:29-32. https://doi.org/10.1016/ j.trstmh.2009.08.001

Champour M, Chinikar S, Mohammadi G, Razmi G, Shah-Hosseini N, Khakifirouz S, Mostafavi E, Jalali T (2016) Molecular epidemiology of Crimean-Congo hemorrhagic fever virus detected from ticks of one humped camels Camelus dromedarius population in northeastern Iran. J Parasit Dis 40:110-115. https://doi.org/10.1007/s12639-014-0458-y

Chan RWY, Hemida MG, Kayali G, Chu DKW, Poon LLM, Alnaeem A, Ali MA, Tao KP, Ng HY, Chan MCW, Guan Y, Nicholls JM, Peiris JSM (2014) Tropism and replication of Middle East respiratory syndrome coronavirus from dromedary camels in the human respiratory tract: an in-vitro and ex-vivo study. Lancet Respir Med 2:813-822. https://doi.org/10.1016/S221326001470158-4
Chan JFW, Lau SKP, To KKW, Cheng VCC, Woo PCY, Yuen K-Y (2015) Middle East respiratory syndrome coronavirus: another zoonotic betacoronavirus causing SARS-Like disease. Clin Microbiol Rev 28:465-522. https://doi.org/10.1128/CMR.0010214

Chevalier V, Pépin M, Plée L, Lancelot R (2010) Rift Valley fevera threat for Europe? Euro Surveill 15:19506

Chhabra MB, Samantaray S (2012) Sarcocystis and sarcocystosis in India: status and emerging perspectives. J Parasit Dis . https:// doi.org/10.1007/s12639-012-0135-y

Chinikar S, Shah-Hosseini N, Mostafavi E, Moradi M, Khakifirouz S, Jalali T, Fooks AR (2013) Surveillance of Rift Valley fever in Iran between 2001 and 2011. All Res J Biol 4:16-18

Christie AB, Chen TH, Elberg SS (1980) Plague in camels and goats: their role in human epidemics. J Infect Dis 141:724-726. https://doi.org/10.1093/infdis/141.6.724

Chu DKW, Hui KPY, Perera RAPM, Miguel E, Niemeyer D, Zhao J, Channappanavar R, Dudas G, Oladipo JO, Traoré A, FassiFihri O, Ali A, Demissié GF, Muth D, Chan MCW, Nicholls JM, Meyerholz DK, Kuranga SA, Mamo G, Zhou Z, So RTY, Hemida MG, Webby RJ, Roger F, Rambaut A, Poon LLM, Perlman S, Drosten C, Chevalier V, Peiris M (2018) MERS coronaviruses from camels in Africa exhibit region-dependent genetic diversity. Proc Natl Acad Sci 115:3144-3149. https:// doi.org/10.1073/pnas.1718769115

Chu DK, Oladipo JO, Perera RA, Kuranga SA, Chan SM, Poon LL, Peiris M (2015) Middle East respiratory syndrome coronavirus MERS-CoV in dromedary camels in Nigeria 2015. Eurosurveillance. https://doi.org/10.2807/1560-7917.es.2015.20.49.30086

Chu DKW, Poon LLM, Gomaa MM, Shehata MM, Perera RAPM, Abu Zeid D, El Rifay AS, Siu LY, Guan Y, Webby RJ, Ali MA, Peiris M, Kayali G (2014) MERS coronaviruses in dromedary camels, Egypt. Emerg Infect Dis 20:1049-1053. https://doi.org/ 10.3201/eid2006.140299

Cooper CW (1992) Risk factors in transmission of brucellosis from animals to humans in Saudi Arabia. Trans $R$ Soc Trop Med Hyg 86:206-209. https://doi.org/10.1016/0035-92039290575-W

Corman VM, Eckerle I, Memish ZA, Liljander AM, Dijkman R, Jonsdottir H, Juma Ngeiywa KJZ, Kamau E, Younan M, Al Masri M, Assiri A, Gluecks I, Musa BE, Meyer B, Müller MA, Hilali M, Bornstein S, Wernery U, Thiel V, Jores J, Drexler JF, Drosten C (2016) Link of a ubiquitous human coronavirus to dromedary camels. Proc Natl Acad Sci 113:9864-9869. https:// doi.org/10.1073/pnas.1604472113

Corman VM, Ithete NL, Richards LR, Schoeman MC, Preiser W, Drosten C, Drexler JF (2014a) Rooting the phylogenetic tree of Middle East respiratory syndrome coronavirus by characterization of a conspecific virus from an African Bat. J Virol 88:11297-11303. https://doi.org/10.1128/jvi.01498-14

Corman VM, Jores J, Meyer B, Younan M, Liljander A, Said MY, Gluecks I, Lattwein E, Bosch B-J, Drexler JF, Bornstein S, Drosten C, Müller MA (2014b) Antibodies against MERS coronavirus in dromedary camels, Kenya, 1992-2013. Emerg Infect Dis. https://doi.org/10.3201/eid2008.140596

Corman VM, Muth D, Niemeyer D, Drosten C (2018) Hosts and sources of endemic human coronaviruses. In: Advances in virus research, Kielian M, Mettenleiter TC, Roossinck MJ (editors), Academic Press, pp 163-188

Cosivi O, Meslin FX, Daborn CJ, Grange JM (1995) Epidemiology of Mycobacterium bovis infection in animals and humans, with particular reference to Africa. Revue Scientifique et Technique de l'OIE 14:733-746. https://doi.org/10.20506/rst.14.3.875 
Cotten M, Watson SJ, Kellam P, Al-Rabeeah AA, Makhdoom HQ, Assiri A, Al-Tawfiq JA, Alhakeem RF, Madani H, AlRabiah FA, Hajjar SA, Al-nassir WN, Albarrak A, Flemban H, Balkhy HH, Alsubaie S, Palser AL, Gall A, Bashford-Rogers R, Rambaut A, Zumla AI, Memish ZA (2013) Transmission and evolution of the Middle East respiratory syndrome coronavirus in Saudi Arabia: a descriptive genomic study. The Lancet 382:1993-2002. https://doi.org/10.1016/S0140-67361361887-5

Cotten M, Watson SJ, Zumla AI, Makhdoom HQ, Palser AL, Ong SH, Al Rabeeah AA, Alhakeem RF, Assiri A, Al-Tawfiq JA, Albarrak A, Barry M, Shibl A, Alrabiah FA, Hajjar S, Balkhy HH, Flemban H, Rambaut A, Kellam P, Memish ZA (2014) Spread, circulation, and evolution of the Middle East respiratory syndrome coronavirus. mBio 5:e1062-13. https://doi.org/10.1128/ mbio.01062-13

Crameri G, Durr PA, Barr J, Yu M, Graham K, Williams OJ, Kayali G, Smith D, Peiris M, Mackenzie JS, Wang L-F (2015) Absence of MERS-CoV antibodies in feral camels in Australia: implications for the pathogen's origin and spread. One Health 1:76-82. https://doi.org/10.1016/j.onehlt.2015.10.003

Deem SL, Fèvre EM, Kinnaird M, Browne AS, Muloi D, Godeke G-J, Koopmans M, Reusken CB (2015) Serological evidence of MERS-CoV antibodies in dromedary camels camelus dromedaries in Laikipia County, Kenya. PLoS ONE 10:e0140125. https://doi.org/10.1371/journal.pone.0140125

Dehkordi FS, Haghighi Borujeni MR, Rahimi E, Abdizadeh R (2013) Detection of Toxoplasma gondii in raw caprine, ovine, buffalo, bovine, and camel milk using cell cultivation, cat bioassay, capture ELISA, and PCR methods in Iran. Foodborne Pathog Disease 10:120-125. https://doi.org/10.1089/fpd.2012. 1311

Devi JP, Noraini W, Norhayati R, Chee Kheong C, Badrul AS, Zainah S, Fadzilah K, Hirman I, Lokman Hakim S, Noor Hisham A (2014) Laboratory-confirmed case of Middle East respiratory syndrome coronavirus MERS-CoV infection in Malaysia: preparedness and response, April 2014. Eurosurveillance 19:20797. https://doi.org/10.2807/1560-7917.es2014.19. 18.20797

Dinkel A, Njoroge EM, Zimmermann A, Wälz M, Zeyhle E, Elmahdi IE, Mackenstedt U, Romig T (2004) A PCR system for detection of species and genotypes of the Echinococcus granulosus-complex, with reference to the epidemiological situation in eastern Africa. Int J Parasitol 34:645-653. https://doi.org/ 10.1016/j.ijpara.2003.12.013

Drancourt M, Houhamdi L, Raoult D (2006) Yersinia pestis as a telluric, human ectoparasite-borne organism. Lancet Infect Dis 6:234-241. https://doi.org/10.1016/S1473-30990670438-8

Drosten C, Muth D, Corman VM, Hussain R, Al Masri M, HajOmar W, Landt O, Assiri A, Eckerle I, Al Shangiti A, AlTawfiq JA, Albarrak A, Zumla A, Rambaut A, Memish ZA (2015) An observational, laboratory-based study of outbreaks of Middle East respiratory syndrome coronavirus in Jeddah and Riyadh, Kingdom of Saudi Arabia, 2014. Clin Infect Dis 60:369377. https://doi.org/10.1093/cid/ciu812

Du L, Han G-Z (2016) Deciphering MERS-CoV Evolution in Dromedary Camels. Trends Microbiol 24:87-89. https://doi.org/ 10.1016/j.tim.2015.12.013

Ducrotoy MJ, Ammary K, Ait Lbacha H, Zouagui Z, Mick V, Prevost L, Bryssinckx W, Welburn SC, Benkirane A (2015) Narrative overview of animal and human brucellosis in Morocco: intensification of livestock production as a driver for emergence? Infect Dis Poverty 4:57. https://doi.org/10.1186/ s40249-015-0086-5
Dudas G, Carvalho LM, Rambaut A, Bedford T (2018) MERS$\mathrm{CoV}$ spillover at the camel-human interface. eLife. https:// doi.org/10.7554/elife.31257

Duraffour S, Meyer H, Andrei G, Snoeck R (2011) Camelpox virus. Antivir Res 92:167-186. https://doi.org/10.1016/j.antiviral.2011.09.003

Durai P, Batool M, Shah M, Choi S (2015) Middle East respiratory syndrome coronavirus: transmission, virology and therapeutic targeting to aid in outbreak control. Exp Mol Med 47:e181. https://doi.org/10.1038/emm.2015.76

Eckerle I, Corman VM, Müller MA, Lenk M, Ulrich RG, Drosten C (2014) Replicative capacity of MERS coronavirus in livestock cell lines. Emerg Infect Dis 20:276-279. https://doi.org/10.3201/ eid2002.131182

Eckert J, Deplazes P (2004) Biological, epidemiological, and clinical aspects of echinococcosis, a zoonosis of increasing concern. Clin Microbiol Rev 17:107-135. https://doi.org/ 10.1128/CMR.17.1.107-135.2004

Eckert J, Thompson RCA, Michael SA, Kumaratilake LM, El-Sawah HM (1989) Echinococcus granulosus of camel origin: development in dogs and parasite morphology. Parasitol Res 75:536-544. https://doi.org/10.1007/BF00931162

El-Ansary EH, Mohammed BA, Hamad AR, Karom AG (2001) Brucellosis among animals and human contacts in eastern Sudan. Saudi Med J 22:577-579

El-Bahnasawy MM, Gabr MSA, Abdel-Fattah MA, Gaber WAI, Morsy TA (2012) Is plague a problem in the Egyptians returning back from Libya? J Egypt Soc Parasitol 42:329-348

El-Bahnasawy MMM, Morsy ATA, Morsy TA (2015) The arthropod-borne onchocerciasis: is it deserved to be neglected? J Egypt Soc Parasitol 45:639-654

El Bushra HE, Abdalla MN, Al Arbash H, Alshayeb Z, Al-Ali S, Latif ZA-A, Al-Bahkit H, Abdalla O, Mohammed M, Al-Abdely H, Chahed M, Lohiniva AL, Saeed AB (2016) An outbreak of Middle East respiratory syndrome MERS due to coronavirus in Al-Ahssa Region, Saudi Arabia, 2015. East Mediterr Health J 22:468-475

El Mamy ABO, Baba MO, Barry Y, Isselmou K, Dia ML, Hampate B, Diallo MY, El Kory MOB, Diop M, Lo MM, Thiongane Y, Bengoumi M, Puech L, Plee L, Claes F, de La Rocque S, Doumbia B (2011) Unexpected rift valley fever outbreak, Northern Mauritania. Emerg Infect Dis 17:1894-1896. https:// doi.org/10.3201/eid1710.110397

El Mamy AB, Lo MM, Thiongane $\mathrm{Y}$, Diop $\mathrm{M}$, Isselmou $\mathrm{K}$, Doumbia B, Baba MO, El Arbi AS, Lancelot R, Kane Y, Albina E, Cêtre-Sossah C (2014) Comprehensive phylogenetic reconstructions of Rift Valley fever virus: the 2010 Northern Mauritania Outbreak in the camelus dromedarius species. Vector Borne Zoonotic Dis 14:856-861. https://doi.org/10.1089/ vbz.2014.1605

Elmahdi IE, Ali QM, Magzoub MMA, Ibrahim AM, Saad MB, Romig T (2004) Cystic echinococcosis of livestock and humans in central Sudan. Ann Trop Med Parasitol 98:473-479. https:// doi.org/10.1179/000349804225003578

Engering A, Hogerwerf L, Slingenbergh J (2013) Pathogen-hostenvironment interplay and disease emergence. Emerg Microb Infect 2:e5-e5. https://doi.org/10.1038/emi.2013.5

Ereqat S, Nasereddin A, Vayssier-Taussat M, Abdelkader A, AlJawabreh A, Zaid T, Azmi K, Abdeen Z (2016) Molecular evidence of bartonella species in ixodid ticks and domestic animals in palestine. Front Microbiol. https://doi.org/10.3389/fmicb. 2016.01217 
Fadlelmula A, Al-Hamam NA, Al-Dughaym AM (2016) A potential camel reservoir for extended-spectrum $\beta$-lactamaseproducing Escherichia coli causing human infection in Saudi Arabia. Trop Anim Health Prod 48:427-433. https://doi.org/ 10.1007/s11250-015-0970-9

Fanoy EB, van der Sande MA, Kraaij-Dirkzwager M, Dirksen K, Jonges M, van der Hoek W, Koopmans MP, der Werf D, Sonder G, van der Weijden C, der Heuvel J, Gelinck L, Bouwhuis JW, van Gageldonk-Lafeber ABon behalf of the members of the MERS-CoV outbreak investigation team of The Netherlands (2014) Travel-related MERS-CoV cases: an assessment of exposures and risk factors in a group of Dutch travellers returning from the Kingdom of Saudi Arabia, May 2014. Emerg Themes Epidemiol 11:16. https://doi.org/10.1186/1742-7622-1116

Farag EABA, Reusken CBEM, Haagmans BL, Mohran KA, Raj VS, Pas SD, Voermans J, Smits SL, Godeke G-J, Al-Hajri MM, Alhajri FH, Al-Romaihi HE, Ghobashy H, El-Maghraby MM, ElSayed AM, Al Thani MHJ, Al-Marri S, Koopmans MPG (2015) High proportion of MERS-CoV shedding dromedaries at slaughterhouse with a potential epidemiological link to human cases, Qatar 2014. Infect Ecol Epidemiol 5:28305. https://doi.org/ 10.3402/iee.v5.28305

Farjanikish G, Shokrani H (2016) Prevalence and morphopathological characteristics of linguatulosis in one-humped camel Camelus dromedarius in Yazd, Iran. Parasitol Res 115:31633167. https://doi.org/10.1007/s00436-016-5074-6

Faye O, Ba H, Ba Y, Freire CCM, Faye O, Ndiaye O, Elgady IO, Zanotto PMA, Diallo M, Sall AA (2014) Reemergence of Rift Valley fever, Mauritania, 2010. Emerg Infect Dis 20:300-303. https://doi.org/10.3201/eid2002.130996

Fehr AR, Channappanavar R, Perlman S (2017) Middle East respiratory syndrome: emergence of a pathogenic human coronavirus. Annu Rev Med 68:387-399. https://doi.org/ 10.1146/annurev-med-051215-031152

Ferguson NM, Van Kerkhove MD (2014) Identification of MERSCoV in dromedary camels. Lancet Infect Dis 14:93-94. https:// doi.org/10.1016/S1473-30991370691-1

Fiori PL, Mastrandrea S, Rappelli P, Cappuccinelli P (2000) Brucella abortus infection acquired in microbiology laboratories. J Clin Microbiol 38:2005-2006

Food and Agriculture Organization of the United Nations FAO (2017) Human exposure to Middle East respiratory syndrome coronavirus from livestock or wildlife species August 2017. FAO Animal Health Risk Analysis-Assessment, Issue No. 4. Rome, FAO

FAOSTAT (2016) Food and agriculture organization corporate statistical database. http://www.fao.org/faostat/en/\#data. Accessed 12 Apr 2018

Funk AL, Goutard FL, Miguel E, Bourgarel M, Chevalier V, Faye B, Peiris JSM, Van Kerkhove MD, Roger FL (2016) MERS-CoV at the animal-human interface: inputs on exposure pathways from an expert-opinion elicitation. Front Vet Sci. https://doi. org/10.3389/fvets.2016.00088

Garcell HG, Garcia EG, Pueyo PV, Martín IR, Arias AV, Alfonso Serrano RN (2016) Outbreaks of brucellosis related to the consumption of unpasteurized camel milk. J Infect Public Health 9:523-527. https://doi.org/10.1016/j.jiph.2015.12.006

Gardner LM, MacIntyre C (2014) Unanswered questions about the Middle East respiratory syndrome coronavirus MERS-CoV. BMC Res Notes 7:358. https://doi.org/10.1186/1756-0500-7-358
Garine-Wichatitsky MD, Caron A, Kock R, Tschopp R, Munyeme M, Hofmeyr M, Michel A (2013) A review of bovine tuberculosis at the wildlife-livestock-human interface in sub-Saharan Africa. Epidemiol Infect 141:1342-1356. https://doi.org/10.1017/ S0950268813000708

Gautret P, Benkouiten S, Gaillard C, Parola P, Brouqui P (2013) Camel milk-associated infection risk perception and knowledge in French Hajj Pilgrims. Vector Borne Zoonotic Dis 13:425-427. https://doi.org/10.1089/vbz.2012.1010

Gerdes GH (2004) Rift Valley fever. Revue scientifique et technique Int Off Epizoot 23:613-624

Ghenghesh KS, El-Ghodban A, Dkakni R, Abeid S, Altomi A, Abdussalam T, Marialigeti K (2001) Prevalence, species differentiation, haemolytic activity, and antibiotic susceptibility of aeromonads in untreated well water. Memórias do Instituto Oswaldo Cruz 96:169-173. https://doi.org/10.1590/S007402762001000200006

Ghoneim NH, Abdel-Moein KA, Zaher H (2017) Camel as a transboundary vector for emerging exotic Salmonella serovars. Pathog Glob Health 111:143-147. https://doi.org/10.1080/ 20477724.2017.1309343

Ghosh S, Gatheru Z, Nyangao J, Adachi N, Urushibara N, Kobayashi N (2011) Full genomic analysis of a G8P[1] rotavirus strain isolated from an asymptomatic infant in Kenya provides evidence for an artiodactyl-to-human interspecies transmission event. J Med Virol 83:367-376. https://doi.org/10.1002/ jmv.21974

Ghosh P, Hsu C, Alyamani EJ, Shehata MM, Al-Dubaib MA, AlNaeem A, Hashad M, Mahmoud OM, Alharbi KBJ, Al-Busadah K, Al-Swailem AM, Talaat AM (2012) Genome-wide analysis of the emerging infection with mycobacterium avium subspecies paratuberculosis in the Arabian Camels Camelus dromedarius. PLoS ONE 7:e31947. https://doi.org/10.1371/journal.pone.0031947

Godfroid J, Cloeckaert A, Liautard J-P, Kohler S, Fretin D, Walravens K, Garin-Bastuji B, Letesson J-J (2005) From the discovery of the Malta fever?s agent to the discovery of a marine mammal reservoir, brucellosis has continuously been a reemerging zoonosis Vet Res 36:313-326. https://doi.org/10.1051/ vetres:2005003

Godfroid J, Al Dahouk S, Pappas G, Roth F, Matope G, Muma J, Marcotty T, Pfeiffer D, Skjerve E (2013) A "One Health" surveillance and control of brucellosis in developing countries: moving away from improvisation. Comp Immunol Microbiol Infect Dis 36:241-248. https://doi.org/10.1016/j.cimid.2012.09.001

Gossner C, Danielson N, Gervelmeyer A, Berthe F, Faye B, Kaasik Aaslav K, Adlhoch C, Zeller H, Penttinen P, Coulombier D (2016) Human-dromedary camel interactions and the risk of acquiring zoonotic Middle East respiratory syndrome coronavirus infection. Zoonoses Public Health 63:1-9. https://doi.org/ 10.1111/zph.12171

Gumaa MM, Osman HM, Omer MM, El Sanousi EM, Godfroid J, Ahmed AM (2014) Seroprevalence of brucellosis in sheep and isolation of Brucella abortus biovar 6 in Kassala State, Eastern Sudan. Revue Scientifique Et Technique Int Off Epizoot 33:957965

Gumi B, Schelling E, Berg S, Firdessa R, Erenso G, Mekonnen W, Hailu E, Melese E, Hussein J, Aseffa A, Zinsstag J (2012) Zoonotic transmission of tuberculosis between pastoralists and their 
livestock in South-East Ethiopia. EcoHealth 9:139-149. https:// doi.org/10.1007/s10393-012-0754-x

Gutiérrez C, Tejedor-Junco MT, González M, Lattwein E, Renneker S (2015) Presence of antibodies but no evidence for circulation of MERS-CoV in dromedaries on the Canary Islands, 2015. Eurosurveillance. https://doi.org/10.2807/1560-7917.es. 2015.20.37.30019

Gwida M, Al Dahouk S, Melzer F, Rösler U, Neubauer H, Tomaso $\mathrm{H}$ (2010) Brucellosis: regionally emerging zoonotic disease? Croat Med J 51:289-295. https://doi.org/10.3325/cmj.2010. 51.289

Gwida M, El-Gohary A, Melzer F, Khan I, Rösler U, Neubauer H (2012) Brucellosis in camels. Res Vet Sci 92:351-355. https:// doi.org/10.1016/j.rvsc.2011.05.002

Gwida MM, El-Gohary AH, Melzer F, Tomaso H, Rosler U, Wernery U, Wernery R, Elschner MC, Khan I, Eickhoff M, Schoner D, Neubauer H (2011) Comparison of diagnostic tests for the detection of Brucella spp. in camel sera. BMC Res Notes 4:525. https://doi.org/10.1186/1756-0500-4-525

Haagmans BL, Al Dhahiry SHS, Reusken CBEM, Raj VS, Galiano M, Myers R, Godeke G-J, Jonges M, Farag E, Diab A, Ghobashy $\mathrm{H}$, Alhajri F, Al-Thani M, Al-Marri SA, Al Romaihi HE, Al Khal A, Bermingham A, Osterhaus ADME, AlHajri MM, Koopmans MPG (2014) Middle East respiratory syndrome coronavirus in dromedary camels: an outbreak investigation. Lancet Infect Dis 14:140-145. https://doi.org/10.1016/S1473-30991370690-X

Haagmans BL, van den Brand JMA, Raj VS, Volz A, Wohlsein P, Smits SL, Schipper D, Bestebroer TM, Okba N, Fux R, Bensaid A, Solanes Foz D, Kuiken T, Baumgartner W, Segales J, Sutter G, Osterhaus ADME (2016) An orthopoxvirus-based vaccine reduces virus excretion after MERS-CoV infection in dromedary camels. Science 351:77-81. https://doi.org/10.1126/science.aad 1283

Haddadzadeh HR, Athari SS, Abedini R, Khazraii Nia S, Khazraii nia P, Nabian S, Haji-Mohamadi B (2010) One-humped camel Camelus dromedarius infestation with Linguatula serrata in Tabriz, Iran. Iran J Arthropod-Borne Dis 4:54-59

Haddaway NR, Collins AM, Coughlin D, Kirk S (2015) The role of google scholar in evidence reviews and its applicability to grey literature searching. PLoS ONE 10:e0138237. https://doi.org/ 10.1371/journal.pone.0138237

Hailemariam Z, Nakao M, Menkir S, Lavikainen A, Yanagida T, Okamoto M, Ito A (2012) Molecular identification of unilocular hydatid cysts from domestic ungulates in Ethiopia: Implications for human infections. Parasitol Int 61:375-377. https://doi.org/ 10.1016/j.parint.2012.01.007

Hajialilo E, Harandi MF, Sharbatkhori M, Mirhendi H, Rostami S (2012) Genetic characterization of Echinococcus granulosus in camels, cattle and sheep from the south-east of Iran indicates the presence of the G3 genotype. J Helminthol 86:263-270. https://doi.org/10.1017/S0022149X11000320

Han HJ, Yu H, Yu XJ (2016) Evidence for zoonotic origins of Middle East respiratory syndrome coronavirus. J Gen Virol 97:274-280. https://doi.org/10.1099/jgv.0.000342

Fasihi Harandi M, Hobbs RP, Adams PJ, Mobedi I, Morgan-Ryan UM, Thompson RCA (2002) Molecular and morphological characterization of Echinococcus granulosus of human and animal origin in Iran. Parasitology 125:367-373. https://doi.org/ 10.1017/S0031182002002172

Haridy FM, El-Metwally MT, Khalil HH, Morsy TA (2011) Trypanosoma evansi in dromedary camel: with a case report of zoonosis in greater Cairo, Egypt. J Egypt Soc Parasitol 41:65-76
Hassanain MA, Shaapan RM, Khalil FAM (2016) Sero-epidemiological value of some hydatid cyst antigen in diagnosis of human cystic echinococcosis. J Parasit Dis 40:52-56. https:// doi.org/10.1007/s12639-014-0443-5

Hemida MG, Al-Naeem A, Perera RAPM, Chin AWH, Poon LLM, Peiris M (2015) Lack of Middle East respiratory syndrome coronavirus transmission from infected camels. Emerg Infect Dis 21:699-701. https://doi.org/10.3201/eid2104.141949

Hemida MG, Chu DKW, Poon LLM, Perera RAPM, Alhammadi MA, Ng H, Siu LY, Guan Y, Alnaeem A, Peiris M (2014) MERS coronavirus in dromedary camel Herd, Saudi Arabia. Emerg Infect Dis. https://doi.org/10.3201/eid2007.140571

Hemida MG, Elmoslemany A, Al-Hizab F, Alnaeem A, Almathen F, Faye B, Chu DKW, Perera RAPM, Peiris M (2017) Dromedary camels and the transmission of Middle East respiratory syndrome coronavirus MERS-CoV. Transbound Emerg Dis 64:344-353. https://doi.org/10.1111/tbed.12401

Hemida M, Perera R, Wang P, Alhammadi M, Siu L, Li M, Poon L, Saif L, Alnaeem A, Peiris M (2013) Middle East respiratory syndrome MERS coronavirus seroprevalence in domestic livestock in Saudi Arabia, 2010-2013. Eurosurveillance 18:20659. https://doi.org/10.2807/1560-7917.ES2013.18.50.20659

Holmes D (2014) MERS-CoV enigma deepens as reported cases surge. Lancet 383:1793. https://doi.org/10.1016/S014067361460866-7

Horton KC, Wasfy M, Samaha H, Abdel-Rahman B, Safwat S, Abdel Fadeel M, Mohareb E, Dueger E (2014) Serosurvey for zoonotic viral and bacterial pathogens among slaughtered livestock in Egypt. Vector Borne Zoonotic Dis 14:633-639. https:// doi.org/10.1089/vbz.2013.1525

Hunter JC, Nguyen D, Aden B, Al Bandar Z, Al Dhaheri W, Abu Elkheir K, Khudair A, Al Mulla M, El Saleh F, Imambaccus H, Al Kaabi N, Sheikh FA, Sasse J, Turner A, Abdel Wareth L, Weber S, Al Ameri A, Abu Amer W, Alami NN, Bunga S, Haynes LM, Hall AJ, Kallen AJ, Kuhar D, Pham H, Pringle K, Tong S, Whitaker BL, Gerber SI, Al Hosani FI (2016) Transmission of Middle East respiratory syndrome coronavirus infections in healthcare settings, Abu Dhabi. Emerg Infect Dis 22:647-656. https://doi.org/10.3201/eid2204.151615

Ikegami T, Makino S (2011) The pathogenesis of Rift Valley fever. Viruses 3:493-519. https://doi.org/10.3390/v3050493

IUCN (2008) Camelus ferus: the IUCN red list of threatened species 2008: e. T63543a12689285

Jäckel S, Eiden M, El Mamy BO, Isselmou K, Vina-Rodriguez A, Doumbia B, Groschup MH (2013) Molecular and serological studies on the Rift Valley fever outbreak in Mauritania in 2010. Transbound Emerg Dis 60:31-39. https://doi.org/10.1111/ tbed. 12142

Jaros P, Cogger N, French N (2008) A systematic review of the human disease evidence associated with the consumption of raw milk and raw milk cheeses. Massey Univ 92:5

Jere KC, Esona MD, Ali YH, Peenze I, Roy S, Bowen MD, Saeed IK, Khalafalla AI, Nyaga MM, Mphahlele J, Steele D, Seheri ML (2014) Novel NSP1 genotype characterised in an African camel G8P[11] rotavirus strain. Infect Genet Evol 21:58-66. https:// doi.org/10.1016/j.meegid.2013.10.002

Jezek Z, Kríz B, Rothbauer V (1983) Camelpox and its risk to the human population. J Hyg Epidemiol Microbiol Immunol 27:2942

Kaindi DWM, Schelling E, Wangoh JM, Imungi JK, Farah Z, Meile L (2012) Risk factors for symptoms of gastrointestinal illness in Rural Town Isiolo, Kenya: Symptoms of gastroin- 
testinal illness in Rural Town Isiolo. Zoonoses Public Health 59:118-125. https://doi.org/10.1111/j.1863-2378.2011.01425.x

Kamenetzky L, Gutierrez AM, Canova SG, Haag KL, Guarnera EA, Parra A, García GE, Rosenzvit MC (2002) Several strains of Echinococcus granulosus infect livestock and humans in Argentina. Infect Genet Evol 2:129-136. https://doi.org/10.1016/S156713480200131-4

Karimi M, Ghasemikhah R, Mirahmadi H, Spotin A, Rouhani S, Seyyed Tabaei SJ (2017) Discrimination of mixed infections of echinococcus species based on in silico sequence analysis: a new way of reflecting overlapped strains in indigenous areas. Arch Clin Infect Dis 12:4. https://doi.org/10.5812/archcid.14168

Kayali G, Peiris M (2015) A more detailed picture of the epidemiology of Middle East respiratory syndrome coronavirus. Lancet Infect Dis 15:495-497. https://doi.org/10.1016/S147330991570128-3

Khalafalla AI, Lu X, Al-Mubarak AIA, Dalab AHS, Al-Busadah KAS, Erdman DD (2015) MERS-CoV in upper respiratory tract and lungs of dromedary camels, Saudi Arabia, 2013-2014. Emerg Infect Dis 21:1153-1158. https://doi.org/10.3201/ eid2107.150070

Khalafalla AI, Abdelazim F (2017) Human and dromedary camel infection with camelpox virus in Eastern Sudan. Vector Borne Zoonotic Dis 17:281-284. https://doi.org/10.1089/vbz.2016.2070

Khan AS, Maupin GO, Rollin PE, Noor AM, Shurie HH, Shalabi AG, Wasef S, Haddad YM, Sadek R, Ijaz K, Peters CJ, Ksiazek TG (1997) An outbreak of crimean-congo hemorrhagic fever in the United Arab Emirates, 1994-1995. Am J Trop Med Hyg 57:519-525. https://doi.org/10.4269/ajtmh.1997.57.519

Khuroo MS, Khuroo MS (2016) Hepatitis E: an emerging global disease-from discovery towards control and cure. J Viral Hepatitis 23:68-79. https://doi.org/10.1111/jvh.12445

Kia EB, Rahimi H, Sharbatkhori M, Talebi A, Fasihi Harandi M, Mirhendi H (2010) Genotype identification of human cystic echinococcosis in Isfahan, central Iran. Parasitol Res 107:757760. https://doi.org/10.1007/s00436-010-1947-2

Kiel FW, Yousuf KM (1989) Brucellosis in Saudi Arabia. Soc Sci Med 29:999-1001. https://doi.org/10.1016/0277-95368990056-7

Kinkar L, Laurimäe T, Sharbatkhori M, Mirhendi H, Kia EB, Ponce-Gordo F, Andresiuk V, Simsek S, Lavikainen A, Irshadullah M, Umhang G, Oudni-M'rad M, Acosta-Jamett G, Rehbein S, Saarma U (2017) New mitogenome and nuclear evidence on the phylogeny and taxonomy of the highly zoonotic tapeworm Echinococcus granulosus sensu stricto. Infect Genet Evol 52:52-58. https://doi.org/10.1016/j.meegid.2017.04.023

Kleinerman G, Baneth G, Mumcuoglu KY, van Straten M, Berlin D, Apanaskevich DA, Abdeen Z, Nasereddin A, Harrus S (2013) Molecular detection of Rickettsia africae, Rickettsia aeschlimannii, and Rickettsia sibirica mongolitimonae in Camels and Hyalomma spp. Ticks from Israel. Vector Borne Zoonotic Dis 13:851856. https://doi.org/10.1089/vbz.2013.1330

Klemmer J, Njeru J, Emam A, El-Sayed A, Moawad AA, Henning K, Elbeskawy MA, Sauter-Louis C, Straubinger RK, Neubauer H, El-Diasty MM (2018) Q fever in Egypt: epidemiological survey of Coxiella burnetii specific antibodies in cattle, buffaloes, sheep, goats and camels. PLoS ONE 13:e0192188. https:// doi.org/10.1371/journal.pone.0192188

Kupferschmidt K (2014) The camel connection. Science 343:14221425. https://doi.org/10.1126/science.343.6178.1422

Kupferschmidt K (2015) MERS surges again, but pandemic jitters ease. Science 347:1296-1297. https://doi.org/10.1126/science.347.6228.1296
Latif AA, Tanveer A, Maqbool A, Siddiqi N, Kyaw-Tanner M, Traub RJ (2010) Morphological and molecular characterisation of Echinococcus granulosus in livestock and humans in Punjab, Pakistan. Vet Parasitol 170:44-49. https://doi.org/10.1016/j.vetpar.2010.02.003

Lee G-H, Tan B-H, Chi-Yuan Teo E, Lim S-G, Dan Y-Y, Wee A, Kim Aw PP, Zhu Y, Hibberd ML, Tan C-K, Purdy MA, Teo C-G (2016) Chronic infection with camelid hepatitis e virus in a liver transplant recipient who regularly consumes camel meat and milk. Gastroenterology 150:355-357.e3. https://doi.org/10.1053/ j.gastro.2015.10.048

Leslie T, Whitehouse CA, Yingst S, Baldwin C, Kakar F, Mofleh J, Hami AS, Mustafa L, Omar F, Ayazi E, Rossi C, Noormal B, Ziar N, Kakar R (2011) Outbreak of gastroenteritis caused by Yersinia pestis in Afghanistan. Epidemiol Infect 139:728-735. https://doi.org/10.1017/S0950268810001792

Liljander A, Meyer B, Jores J, Müller MA, Lattwein E, Njeru I, Bett B, Drosten C, Corman VM (2016) MERS-CoV Antibodies in Humans, Africa, 2013-2014. Emerg Infect Dis 22:1086-1089. https://doi.org/10.3201/eid2206.160064

Linthicum KJ, Britch SC, Anyamba A (2016) Rift Valley fever: an emerging mosquito-borne disease. Annu Rev Entomol 61:395415. https://doi.org/10.1146/annurev-ento-010715-023819

Lutomiah J, Omondi D, Masiga D, Mutai C, Mireji PO, Ongus J, Linthicum KJ, Sang R (2014) Blood meal analysis and virus detection in blood-fed mosquitoes collected during the 20062007 Rift Valley fever outbreak in Kenya. Vector Borne Zoonotic Dis 14:656-664. https://doi.org/10.1089/vbz.2013.1564

Mackay IM, Arden KE (2015) Middle East respiratory syndrome: an emerging coronavirus infection tracked by the crowd. Virus Res 202:60-88. https://doi.org/10.1016/j.virusres.2015.01.021

Mackay I, Arden K (2017) An opportunistic pathogen afforded ample opportunities: Middle East respiratory syndrome coronavirus. Viruses 9:369. https://doi.org/10.3390/v9120369

Macpherson CNL, McManus DP (1982) A comparative study of Echinococcus granulosus from human and animal hosts in Kenya using isoelectric focusing and isoenzyme analysis. Int J Parasitol 12:515-521. https://doi.org/10.1016/0020-75198290046-7

Macpherson CNL, Smyth JD (1985) In vitro culture of the strobilar stage of Echinococcus granulosus from protoscoleces of human, camel, cattle, sheep and goat origin from Kenya and buffalo origin from India. Int J Parasitol 15:137-140. https:// doi.org/10.1016/0020-75198590078-

Maillard S, Benchikh-Elfegoun MC, Knapp J, Bart JM, Koskei P, Gottstein B, Piarroux R (2006) Taxonomic position and geographical distribution of the common sheep G1 and camel G6 strains of Echinococcus granulosus in three African countries. Parasitol Res 100:495-503. https://doi.org/10.1007/s00436-0060286-9

Majumder M (2015) Middle East respiratory syndrome in the Kingdom of Saudi Arabia: insights from publicly available data. Thesis, Massachusetts Institute of Technology

Mandal S, Deb Mandal M (2012) Human cystic echinococcosis: epidemiologic, zoonotic, clinical, diagnostic and therapeutic aspects. Asian Pac J Trop Med 5:253-260. https://doi.org/ 10.1016/S1995-76451260035-2

McCarthy J, Moore TA (2000) Emerging helminth zoonoses. Int J Parasitol 30:1351-1359. https://doi.org/10.1016/S002075190000122-3

McManus DP (1981) A biochemical study of adult and cystic stages of Echinococcus granulosus of human and animal origin 
from Kenya. J Helminthol 55:21-28. https://doi.org/10.1017/ S0022149X00025414

McManus DP, Rishi AK (1989) Genetic heterogeneity within Echinococcus granulosus: isolates from different hosts and geographical areas characterized with DNA probes. Parasitology 99:17-29. https://doi.org/10.1017/S0031182000060984

Megersa B, Biffa D, Abunna F, Regassa A, Godfroid J, Skjerve E (2011) Seroprevalence of brucellosis and its contribution to abortion in cattle, camel, and goat kept under pastoral management in Borana, Ethiopia. Trop Anim Health Prod 43:651656. https://doi.org/10.1007/s11250-010-9748-2

Megersa B, Biffa D, Abunna F, Regassa A, Godfroid J, Skjerve E (2012) Seroepidemiological study of livestock brucellosis in a pastoral region. Epidemiol Infect 140:887-896. https://doi.org/ $10.1017 /$ S0950268811001178

Memish ZA, Alsahly A, Masri M, Heil GL, Anderson BD, Peiris M, Khan SU, Gray GC (2015) Sparse evidence of MERS-CoV infection among animal workers living in Southern Saudi Arabia during 2012. Influenza Other Respir Viruses 9:64-67. https://doi.org/10.1111/irv.12287

Memish ZA, Balkhy HH (2004) Brucellosis and international travel. J Travel Med 11:49-55. https://doi.org/10.2310/ 7060.2004.13551

Memish ZA, Cotten M, Meyer B, Watson SJ, Alsahafi AJ, Al Rabeeah AA, Corman VM, Sieberg A, Makhdoom HQ, Assiri A, Al Masri M, Aldabbagh S, Bosch B-J, Beer M, Müller MA, Kellam P, Drosten C (2014) Human infection with MERS coronavirus after exposure to infected Camels, Saudi Arabia, 2013. Emerg Infect Dis 20:1012-1015. https://doi.org/10.3201/eid2006.140402

Memish ZA, Cotten M, Watson SJ, Kellam P, Zumla A, Alhakeem RF, Assiri A, Rabeeah AAA, Al-Tawfiq JA (2014) Community case clusters of Middle East respiratory syndrome coronavirus in Hafr Al-Batin, Kingdom of Saudi Arabia: a descriptive genomic study. Int $J$ Infect Dis 23:63-68. https://doi.org/ 10.1016/j.ijid.2014.03.1372

Merrill HR, Khan SU, Anderson BD, Heil GL, Alsahly A, Memish ZA, Gray GC, Masri MA (2015) Elevated antibodies against Rift Valley fever virus among humans with exposure to ruminants in Saudi Arabia. Am J Trop Med Hyg 92:739-743. https://doi.org/ 10.4269/ajtmh.14-0575

Memish ZA, Zumla AI, Al-Hakeem RF, Al-Rabeeah AA, Stephens GM (2013) Family cluster of Middle East respiratory syndrome coronavirus infections. N Engl J Med 368:2487-2494. https:// doi.org/10.1056/NEJMoa1303729

Mertens M, Schmidt K, Ozkul A, Groschup MH (2013) The impact of Crimean-Congo hemorrhagic fever virus on public health. Antivir Res 98:248-260. https://doi.org/10.1016/j.antiviral.2013.02.007

Meyer B, Juhasz J, Barua R, Das Gupta A, Hakimuddin F, Corman VM, Müller MA, Wernery U, Drosten C, Nagy P (2016) Time course of MERS-CoV infection and immunity in dromedary camels. Emerg Infect Dis 22:2171-2173. https://doi.org/10.3201/ eid2212.160382

Meyer B, Müller MA, Corman VM, Reusken CBEM, Ritz D, Godeke G-J, Lattwein E, Kallies S, Siemens A, van Beek J, Drexler JF, Muth D, Bosch B-J, Wernery U, Koopmans MPG, Wernery R, Drosten C (2014) Antibodies against MERS Coronavirus in dromedary camels, United Arab Emirates, 2003 and 2013. Emerg Infect Dis 20:552-559. https://doi.org/10.3201/ eid2004.131746

Miguel E, Chevalier V, Ayelet G, Ben Bencheikh MN, Boussini H, Chu DK, El Berbri I, Fassi-Fihri O, Faye B, Fekadu G, Grosbois
V, Ng BC, Perera RA, So T, Traore A, Roger F, Peiris M (2017) Risk factors for MERS coronavirus infection in dromedary camels in Burkina Faso, Ethiopia, and Morocco, 2015. Eurosurveillance 22:30498. https://doi.org/10.2807/15607917.ES.2017.22.13.30498

Miguel E, Perera RAPM, Baubekova A, Chevalier V, Faye B, Akhmetsadykov N, Ng CY, Roger F, Peiris M (2016) Absence of Middle East respiratory syndrome coronavirus in Camelids, Kazakhstan, 2015. Emerg Infect Dis 22:555-557. https://doi.org/ 10.3201/eid2203.151284

Mirzaei M, Rezaei H, Nematollahi A, Ashrafihelan J (2016) Survey of hydatidosis infection in slaughtered camel Camelus dromedarius in Tabriz area, Northwest Iran. J Parasit Dis 40:444-447. https://doi.org/10.1007/s12639-014-0523-6

Moallin ASM, Zessin KH (1988) Outbreak of camel contagious ecthyma in central Somalia. Trop Anim Health Prod 20:185-186. https://doi.org/10.1007/BF02240091

Mohabbati Mobarez A, Bagheri Amiri F, Esmaeili S (2017) Seroprevalence of Q fever among human and animal in Iran: a systematic review and meta-analysis. PLOS Negl Trop Dis 11:e0005521. https://doi.org/10.1371/journal.pntd.0005521

Mobedi I, Madadi H, Arfaa F (1970) Camel, Camelus dromedarius, as intermediate host of Echinococcus granulosus in Iran. J Parasitol 56:1255. https://doi.org/10.2307/3277581

Moda G, Daborn CJ, Grange JM, Cosivi O (1996) The zoonotic importance of Mycobacterium bovis. Tuber Lung Dis 77:103-108. https://doi.org/10.1016/S0962-84799690022-2

Mohd HA, Al-Tawfiq JA, Memish ZA (2016) Middle East respiratory syndrome coronavirus MERS-CoV origin and animal reservoir. Virol J 13:87. https://doi.org/10.1186/s12985-0160544-0

M'rad S, Filisetti D, Oudni M, Mekki M, Belguith M, Nouri A, Sayadi T, Lahmar S, Candolfi E, Azaiez R, Mezhoud H, Babba H (2005) Molecular evidence of ovine G1 and camel G6 strains of Echinococcus granulosus in Tunisia and putative role of cattle in human contamination. Vet Parasitol 129:267-272. https:// doi.org/10.1016/j.vetpar.2005.02.006

Muhairi SA, Hosani FA, Eltahir YM, Mulla MA, Yusof MF, Serhan WS, Hashem FM, Elsayed EA, Marzoug BA, Abdelazim AS (2016) Epidemiological investigation of Middle East respiratory syndrome coronavirus in dromedary camel farms linked with human infection in Abu Dhabi Emirate, United Arab Emirates. Virus Genes 52:848-854. https://doi.org/10.1007/s11262-0161367-1

Muloi D, Alarcon P, Ombui J, Ngeiywa KJ, Abdullahi B, Muinde P, Karani MK, Rushton J, Fèvre EM (2018) Value chain analysis and sanitary risks of the camel milk system supplying Nairobi city, Kenya. Prev Vet Med 159:203-210. https://doi.org/10.1016/ j.prevetmed.2018.09.010

Müller MA, Corman VM, Jores J, Meyer B, Younan M, Liljander A, Bosch B-J, Lattwein E, Hilali M, Musa BE, Bornstein S, Drosten C (2014) MERS coronavirus neutralizing antibodies in camels, Eastern Africa, 1983-1997. Emerg Infect Dis 20:20932095. https://doi.org/10.3201/eid2012.141026

Müller MA, Meyer B, Corman VM, Al-Masri M, Turkestani A, Ritz D, Sieberg A, Aldabbagh S, Bosch B-J, Lattwein E, Alhakeem RF, Assiri AM, Albarrak AM, Al-Shangiti AM, Al-Tawfiq JA, Wikramaratna P, Alrabeeah AA, Drosten C, Memish ZA (2015) Presence of Middle East respiratory syndrome coronavirus antibodies in Saudi Arabia: a nationwide, cross-sectional, serological study. Lancet Infect Dis 15:559-564. https://doi.org/ 10.1016/S1473-30991570090-3 
Macharia J, Murithi RM, Wainwright S, Breiman RF, Munyua P, Bloland P, Njenga MK, Githinji J, Hightower A, Ithondeka PM, Mutonga D, Musaa J (2010) Rift Valley fever outbreak in livestock in Kenya, 2006-2007. Am J Trop Med Hyg 83:58-64. https://doi.org/10.4269/ajtmh.2010.09-0292

Musa MT, Shomein AM, El Razig YA, Meki NT, El Hassan SM (1993) Anthrax in humans and camels in the Sudan with reference to the disease in the country. J Trop Livest Sci 46:438439. https://doi.org/10.19182/remvt.9438

Ng DL, Al Hosani F, Keating MK, Gerber SI, Jones TL, Metcalfe MG, Tong S, Tao Y, Alami NN, Haynes LM, Mutei MA, AbdelWareth L, Uyeki TM, Swerdlow DL, Barakat M, Zaki SR (2016) Clinicopathologic, immunohistochemical, and ultrastructural findings of a fatal case of Middle East respiratory syndrome coronavirus infection in the United Arab Emirates, April 2014. Am J Pathol 186:652-658. https://doi.org/10.1016/j.ajpath.2015.10.024

Nimri LF (2003) Diagnosis of recent and relapsed cases of human brucellosis by PCR assay. BMC Infect Dis 3:5. https://doi.org/ 10.1186/1471-2334-3-5

Njeru J, Henning K, Pletz MW, Heller R, Neubauer H 2016 Q fever is an old and neglected zoonotic disease in Kenya: a systematic review. BMC Public Health 16. https://doi.org/10.1186/ s12889-016-2929-9

Nowotny N, Kolodziejek J (2014) Middle East respiratory syndrome coronavirus MERS-CoV in dromedary camels, Oman, 2013. Eurosurveillance 19:20781. https://doi.org/10.2807/15607917.ES2014.19.16.20781

Oksanen A, Lavikainen A (2015) Echinococcus canadensis transmission in the North. Vet Parasitol 213:182-186. https://doi.org/ 10.1016/j.vetpar.2015.07.03

Oladipo JO (2015) Virologic and sero-epidemiological studies of Middle East respiratory syndrome coronavirus MERS-CoV infections in dromedary camels in Nigeria. HKU Theses Online Retrieved

Olival KJ, Epstein J (2015) Animal Reservoirs of Middle East Respiratory Syndrome Coronavirus. In: Emerging viral diseases: the one health connection: workshop summary, vol 1. Washington, DC: National Academies Press, pp 119-132

Omer RA, Dinkel A, Romig T, Mackenstedt U, Elnahas AA, Aradaib IE, Ahmed ME, Elmalik KH, Adam A (2010) A molecular survey of cystic echinococcosis in Sudan. Vet Parasitol 169:340-346. https://doi.org/10.1016/j.vetpar.2010.01.004

Omer MM, Musa MT, Bakhiet MR, Perrett L (2010) Brucellosis in camels, cattle and humans: associations and evaluation of serological tests used for diagnosis of the disease in certain nomadic localities in Sudan. Rev Sci Tech 29:663-669

Omrani AS, Al-Tawfiq JA, Memish ZA (2015) Middle East respiratory syndrome coronavirus MERS-CoV: animal to human interaction. Pathog Glob Health 109:354-362. https://doi.org/ 10.1080/20477724.2015.1122852

Omrani AS, Shalhoub S (2015) Middle East RESPIRATORY SYNDROME coronavirus MERS-CoV: what lessons can we learn? J Hosp Infect 91:188-196. https://doi.org/10.1016/ j.jhin.2015.08.002

Oryan A, Khordadmehr M, Ranjbar VR (2011) Prevalence, biology, pathology, and public health importance of linguatulosis of camel in Iran. Trop Anim Health Prod 43:1225-1231. https:// doi.org/10.1007/s11250-011-9830-4

Osoro EM, Munyua P, Omulo S, Ogola E, Ade F, Mbatha P, Mbabu M, Nganga A, Kairu S, Maritim M, Thumbi S, Bitek A, Gaichugi S, Rubin C, Njenga K, Guerra M (2015) Strong association between human and animal brucella seropositivity in a linked study in Kenya, 2012-2013. Am J Trop Med Hyg 93:224-231. https://doi.org/10.4269/ajtmh.15-0113

Pappas G (2010) The changing Brucella ecology: novel reservoirs, new threats. Int J Antimicrob Agents 36:S8-S11. https://doi.org/ 10.1016/j.ijantimicag.2010.06.013

Park SW, Perera RAPM, Choe PG, Lau EHY, Choi SJ, Chun JY, Oh HS, Song K-H, Bang JH, Kim ES, Kim HB, Park WB, Kim NJ, Poon LLM, Peiris M, Oh MD (2015) Comparison of serological assays in human Middle East respiratory syndrome MERS-coronavirus infection. Eurosurveillance. https://doi.org/ 10.2807/1560-7917.es.2015.20.41.30042

Pavio N, Meng X-J, Doceul V (2015) Zoonotic origin of hepatitis E. Curr Opin Virol 10:34-41. https://doi.org/10.1016/j.coviro.2014.12.006

Paweska JT (2015) Rift Valley fever. Revue Scientifique Et Technique Int Off Epizootics 34:375-389

Pearce-Duvet JMC (2006) The origin of human pathogens: evaluating the role of agriculture and domestic animals in the evolution of human disease. Biol Rev 81:369-382. https:// doi.org/10.1017/S1464793106007020

Pirouz HJ, Mohammadi G, Mehrzad J, Azizzadeh M, Nazem Shirazi MH (2015) Seroepidemiology of Q fever in one-humped camel population in northeast Iran. Trop Anim Health Prod 47:1293-1298. https://doi.org/10.1007/s11250-015-0862-z

QGIS Development Team (2019) QGIS Geographic Information System. Open Source Geospatial Foundation Project. http://qg is.osgeo.org

Rabaan AA (2017) Middle East respiratory syndrome coronavirus: five years later. Expert Rev Respirat Med 11:901-912. https:// doi.org/10.1080/17476348.2017.1367288

Rahimi E, Ameri M, Kazemeini HR (2010) Prevalence and antimicrobial resistance of Campylobacter species isolated from raw camel, beef, lamb, and goat meat in Iran. Foodborne $\mathrm{Pa}$ thogens and Disease 7:443-447. https://doi.org/10.1089/ fpd.2009.0421

Rahimi E, Kazemeini HR, Salajegheh M (2012) Escherichia coli O157:H7/NM prevalence in raw beef, camel, sheep, goat, and water buffalo meat in Fars and Khuzestan provinces, Iran. Vet Res Forum 3:15-17

Rahimi E, Kheirabadi EK (2012) Detection of Helicobacter pylor$i$ in bovine, buffalo, camel, ovine, and caprine milk in Iran. Foodborne Pathog Dis 9:453-456. https://doi.org/10.1089/ fpd.2011.1060

Raj VS, Farag EABA, Reusken CBEM, Lamers MM, Pas SD, Voermans J, Smits SL, Osterhaus ADME, Al-Mawlawi N, Al-Romaihi HE, AlHajri MM, El-Sayed AM, Mohran KA, Ghobashy H, Alhajri F, Al-Thani M, Al-Marri SA, El-Maghraby MM, Koopmans MPG, Haagmans BL (2014) Isolation of MERS coronavirus from a dromedary camel, Qatar, 2014. Emerg Infect Dis 20:1339-1342. https://doi.org/10.3201/eid2008.140663

Rasche A, Saqib M, Liljander AM, Bornstein S, Zohaib A, Renneker S, Steinhagen K, Wernery R, Younan M, Gluecks I, Hilali M, Musa BE, Jores J, Wernery U, Drexler JF, Drosten C, Corman VM (2016) Hepatitis E virus infection in dromedaries, North and East Africa, United Arab Emirates, and Pakistan, 1983-2015. Emerg Infect Dis 22:1249-1252. https://doi.org/ 10.3201/eid2207.160168

Rasis M, Rudoler N, Schwartz D, Giladi M (2014) Bartonella dromedarii sp. nov. Isolated from domesticated camels Camelus dromedarius in Israel. Vector Borne Zoonotic Dis 14:775-782. https://doi.org/10.1089/vbz.2014.1663 
Rasmussen SA, Gerber SI, Swerdlow DL (2015) Middle East respiratory syndrome coronavirus: update for clinicians. Clin Infect Dis 60:1686-1689. https://doi.org/10.1093/cid/civ118

Rasmussen SA, Watson AK, Swerdlow DL (2016) Middle East respiratory syndrome MERS. Microbiol Spectr 4:3. https:// doi.org/10.1128/microbiolspec.EI10-0020-2016

Raufu IA, Odetokun IA, Oladunni FS, Adam M, Kolapo UT, Akorede GJ, Ghali IM, Ameh JA, Ambali A (2015) Serotypes, antimicrobial profiles, and public health significance of Salmonella from camels slaughtered in Maiduguri central abattoir, Nigeria. Vet World 8:1068-1072. https://doi.org/10.14202/vetworld.2015.1068-1072

Reeves T, Samy AM, Peterson AT (2015) MERS-CoV geography and ecology in the Middle East: analyses of reported camel exposures and a preliminary risk map. BMC Res Notes 8:801. https://doi.org/10.1186/s13104-015-1789-1

Reusken C, Ababneh M, Raj V, Meyer B, Eljarah A, Abutarbush S, Godeke G, Bestebroer T, Zutt I, Müller M, Bosch B, Rottier P, Osterhaus A, Drosten C, Haagmans B, Koopmans M (2013) Middle East respiratory syndrome coronavirus MERS-CoV serology in major livestock species in an affected region in Jordan, June to September 2013. Eurosurveillance 18:20662. https://doi.org/10.2807/1560-7917.ES2013.18.50.20662

Reusken CBEM, Farag EABA, Haagmans BL, Mohran KA, Godeke G-J, Raj S, Alhajri F, Al-Marri SA, Al-Romaihi HE, Al-Thani M, Bosch B-J, van der Eijk AA, El-Sayed AM, Ibrahim AK, AlMolawi N, Müller MA, Pasha SK, Drosten C, AlHajri MM, Koopmans MPG (2015) occupational exposure to dromedaries and risk for MERS-CoV Infection, Qatar, 2013-2014. Emerg Infect Dis 21:1422-1425. https://doi.org/10.3201/eid2108.150481

Reusken CB, Farag EA, Jonges M, Godeke GJ, El-Sayed AM, Pas SD, Raj VS, Mohran KA, Moussa HA, Ghobashy H, Alhajri F (2014) Middle East respiratory syndrome coronavirus MERS$\mathrm{CoV}$ RNA and neutralising antibodies in milk collected according to local customs from dromedary camels, Qatar, April 2014. Eurosurveillance 19:23

Reusken CB, Haagmans BL, Müller MA, Gutierrez C, Godeke G-J, Meyer B, Muth D, Raj VS, Vries LS-D, Corman VM, Drexler JF, Smits SL, El Tahir YE, De Sousa R, van Beek J, Nowotny N, van Maanen K, Hidalgo-Hermoso E, Bosch B-J, Rottier P, Osterhaus A, Gortázar-Schmidt C, Drosten C, Koopmans MP (2013) Middle East respiratory syndrome coronavirus neutralising serum antibodies in dromedary camels: a comparative serological study. Lancet Infect Dis 13:859-866. https://doi.org/ 10.1016/S1473-30991370164-6

Reusken CBEM, Messadi L, Feyisa A, Ularamu H, Godeke G-J, Danmarwa A, Dawo F, Jemli M, Melaku S, Shamaki D, Woma Y, Wungak Y, Gebremedhin EZ, Zutt I, Bosch B-J, Haagmans BL, Koopmans MPG (2014) Geographic distribution of MERS coronavirus among dromedary camels, Africa. Emerg Infect Dis 20:1370-1374. https://doi.org/10.3201/eid2008.140590

Reusken CB, Raj VS, Koopmans MP, Haagmans BL (2016) Cross host transmission in the emergence of MERS coronavirus. Curr Opin Virol 16:55-62. https://doi.org/10.1016/j.coviro.2016. 01.004

Reuss A, Litterst A, Drosten C, Seilmaier M, Böhmer M, Graf P, Gold H, Wendtner C-M, Zanuzdana A, Schaade L, Haas W, Buchholz U (2014) Contact investigation for imported case of Middle East respiratory syndrome, Germany. Emerg Infect Dis 20:620-625. https://doi.org/10.3201/eid2004.131375

Rezaei F, Tavassoli M, Javdani M (2012) Prevalence and morphological characterizations of Linguatula serrata nymphs in camels in Isfahan Province, Iran. Vet Res Forum 3:61-65
Rhodes HM, Williams DN, Hansen GT (2016) Invasive human brucellosis infection in travelers to and immigrants from the Horn of Africa related to the consumption of raw camel milk. Travel Med Infect Dis 14:255-260. https://doi.org/10.1016/ j.tmaid.2016.03.013

Roser M (2018) Future population growth. Our world in data. h ttps://ourworldindata.org/future-population-growth. Accessed May 3, 2018

Sabir JSM, Lam TT-Y, Ahmed MMM, Li L, Shen Y, Abo-Aba S, Qureshi MI, Abu-Zeid M, Zhang Y, Khiyami MA, Alharbi NS, Hajrah NH, Sabir MJ, Mutwakil MHZ, Kabli SA, Alsulaimany FAS, Obaid AY, Zhou B, Smith DK, Holmes EC, Zhu H, Guan Y (2016) Co-circulation of three camel coronavirus species and recombination of MERS-CoVs in Saudi Arabia. Science 351:8184. https://doi.org/10.1126/science.aac8608

Sadjjadi SM (2006) Present situation of echinococcosis in the Middle East and Arabic North Africa. Parasitol Int 55:S197S202. https://doi.org/10.1016/j.parint.2005.11.030

Sadjjadi S, Ardehali S, Shojaei A (1998) A case report of linguatula serrata in human pharynx from Shiraz, southern Iran. Med J Islamic Repub Iran 12:193-194

Saeed AAB, Al-Hamdan NA, Fontaine RE (2005) Plague from eating raw camel liver. Emerg Infect Dis 11:1456-1457. https:// doi.org/10.3201/eid1109.050081

Salehi TZ, Tonelli A, Mazza A, Staji H, Badagliacca P, Tamai IA, Jamshidi R, Harel J, Lelli R, Masson L (2012) Genetic characterization of Escherichia coli O157:H7 strains isolated from the one-humped camel Camelus dromedarius by using microarray DNA technology. Mol Biotechnol 51:283-288. https://doi.org/ 10.1007/s12033-011-9466-7

Salem CO, Schneegans F, Chollet J, Jemli M (2011) Epidemiological studies on echinococcosis and characterization of human and livestock hydatid cysts in Mauritania. Iran J Parasitol 6:4957

Salkeld DJ, Stapp P, Tripp DW, Gage KL, Lowell J, Webb CT, Brinkerhoff RJ, Antolin MF (2016) Ecological traits driving the outbreaks and emergence of zoonotic pathogens. Bioscience 66:118-129. https://doi.org/10.1093/biosci/biv179

Saqib M, Sieberg A, Hussain MH, Mansoor MK, Zohaib A, Lattwein E, Müller MA, Drosten C, Corman VM (2017) Serologic evidence for MERS-CoV infection in dromedary camels, Punjab, Pakistan, 2012-2015. Emerg Infect Dis 23:550-551. https:// doi.org/10.3201/eid2303.161285

Sazmand A, Rasooli A, Nouri M, Hamidinejat H, Hekmatimoghaddam S (2012) Prevalence of cryptosporidium spp. In camels and involved people in Yazd province, Iran. Iran J Parasitol 7:80-84

Schelling E, Diguimbaye C, Daoud S, Nicolet J, Boerlin P, Tanner M, Zinsstag J (2003) Brucellosis and Q-fever seroprevalences of nomadic pastoralists and their livestock in Chad. Prev Vet Med 61:279-293. https://doi.org/10.1016/j.prevetmed.2003.08.004

Schelling E, Diguimbaye C, Daoud S, Nicolet J, Zinsstag J (2004) Seroprevalences of zoonotic diseases in nomads and their livestock in Chari-Baguirmi, Chad. Medecine Tropicale: Revue Du Corps De Sante Colonial 64:474-477

Scholz HC, Pearson T, Hornstra H, Projahn M, Terzioglu R, Wernery R, Georgi E, Riehm JM, Wagner DM, Keim PS, Joseph M, Johnson B, Kinne J, Jose S, Hepp CM, Witte A, Wernery U (2014) Genotyping of burkholderia mallei from an outbreak of glanders in Bahrain suggests multiple introduction events. PLoS Negl Trop Dis 8:e3195. https://doi.org/10.1371/journal.pntd. 0003195 
Seleem MN, Boyle SM, Sriranganathan N (2010) Brucellosis: a reemerging zoonosis. Vet Microbiol 140:392-398. https://doi.org/ 10.1016/j.vetmic.2009.06.021

Shaalan MA, Memish ZA, Mahmoud SA, Alomari A, Khan MY, Almuneef M, Alalola S (2002) Brucellosis in children: clinical observations in 115 cases. Int J Infect Dis 6:182-186. https:// doi.org/10.1016/S1201-97120290108-6

Shabana II, Zaraket H, Suzuki H (2013) Molecular studies on diarrhea-associated Escherichia coli isolated from humans and animals in Egypt. Vet Microbiol 167:532-539. https://doi.org/ 10.1016/j.vetmic.2013.08.014

Shahnazi M, Hejazi H, Salehi M, Andalib AR (2011) Molecular characterization of human and animal Echinococcus granulosus isolates in Isfahan, Iran. Acta Tropica 117:47-50. https://doi.org/ 10.1016/j.actatropica.2010.09.002

Shakerian A, Shekarforoush SS, Ghafari Rad H (2008) Prevalence of Linguatula serrata nymphs in one-humped camel Camelus dromedarius in Najaf-Abad, Iran. Res Vet Sci 84:243-245. https://doi.org/10.1016/j.rvsc.2007.04.015

Shapiro M, London B, Nigri D, Shoss A, Zilber E, Fogel I (2016) Middle East respiratory syndrome coronavirus: review of the current situation in the world. Disaster Mil Med 2:9. https:// doi.org/10.1186/s40696-016-0019-2

Shariatzadeh SA, Spotin A, Gholami S, Fallah E, Hazratian T, Mahami-Oskouei M, Montazeri F, Moslemzadeh HR, Shahbazi A (2015) The first morphometric and phylogenetic perspective on molecular epidemiology of Echinococcus granulosus sensu lato in stray dogs in a hyperendemic Middle East focus, northwestern Iran. Parasites Vectors 8:409. https://doi.org/ 10.1186/s13071-015-1025-9

Sharif-Yakan A, Kanj SS (2014) Emergence of MERS-CoV in the Middle East: Origins, Transmission, Treatment, and Perspectives. PLoS Pathog 10:e1004457. https://doi.org/10.1371/journal.ppat.1004457

Sharma SK, Kataria AK, Shringi BN, Nathawat P, Bhati T, Mohammed N (2013) Detection of hypermucoviscous Klebsiella pneumoniae in camel Camelus dromedarius during an outbreak of acute respiratory tract infection. J Camel Pract Res 20:139143

Sharma M, Sehgal R, Fomda BA, Malhotra A, Malla N (2013) Molecular characterization of Echinococcus granulosus cysts in North Indian patients: identification of G1, G3, G5 and G6 genotypes. PLoS Negl Trop Dis 7:e2262. https://doi.org/10.1371/ journal.pntd.0002262

Shchelkunov SN (2013) An increasing danger of zoonotic orthopoxvirus infections. PLoS Pathog 9:e1003756. https://doi.org/ 10.1371/journal.ppat.1003756

Shehata MM, Gomaa MR, Ali MA, Kayali G (2016) Middle East respiratory syndrome coronavirus: a comprehensive review. Front Med 10:120-136. https://doi.org/10.1007/s11684-0160430-6

Shimol SB, Dukhan L, Belmaker I, Bardenstein S, Sibirsky D, Barrett C, Greenberg D (2012) Human brucellosis outbreak acquired through camel milk ingestion in southern Israel. Israel Med Assoc J 14:475-478

Singh BB, Dhand NK, Ghatak S, Gill JPS (2014) Economic losses due to cystic echinococcosis in India: need for urgent action to control the disease. Prev Vet Med 113:1-12. https://doi.org/ 10.1016/j.prevetmed.2013.09.007

Smits HL, Kadri SM (2005) Brucellosis in India: a deceptive infectious disease. Indian J Med Res 122:375-384
Spahr C, Knauf-Witzens T, Vahlenkamp T, Ulrich RG, Johne R (2018) Hepatitis E virus and related viruses in wild, domestic and zoo animals: a review. Zoonoses Public Health 65:11-29. https://doi.org/10.1111/zph.12405

Spotin A, Gholami S, Najafi Nasab A, Fallah E, Oskouei MM, Semnani V, Shariatzadeh SA, Shahbazi A (2015) Designing and conducting in silico analysis for identifying of Echinococcus spp. with discrimination of novel haplotypes: an approach to better understanding of parasite taxonomic. Parasitol Res 114:1503-1509. https://doi.org/10.1007/s00436-015-4334-1

Spotin A, Mahami-Oskouei M, Harandi MF, Baratchian M, Bordbar A, Ahmadpour E, Ebrahimi S (2017) Genetic variability of Echinococcus granulosus complex in various geographical populations of Iran inferred by mitochondrial DNA sequences. Acta Trop 165:10-16. https://doi.org/10.1016/j.actatropica. 2016.03.002

Sprague LD, Al-Dahouk S, Neubauer H (2012) A review on camel brucellosis: a zoonosis sustained by ignorance and indifference. Pathog Glob Health 106:144-149. https://doi.org/10.1179/ 2047773212Y.0000000020

Stenseth NC, Atshabar BB, Begon M, Belmain SR, Bertherat E, Carniel E, Gage KL, Leirs H, Rahalison L (2008) Plague: past, present, and future. PLoS Medicine 5:e3. https://doi.org/10.1371/ journal.pmed.0050003

Su S, Wong G, Shi W, Liu J, Lai ACK, Zhou J, Liu W, Bi Y, Gao GF (2016) Epidemiology, genetic recombination, and pathogenesis of coronaviruses. Trends Microbiol 24:490-502. https:// doi.org/10.1016/j.tim.2016.03.003

Sung JM-L, Lloyd DH, Lindsay JA (2008) Staphylococcus aureus host specificity: comparative genomics of human versus animal isolates by multi-strain microarray. Microbiology 154:19491959. https://doi.org/10.1099/mic.0.2007/015289-0

Swai ES, Sindato C (2015) Seroprevalence of Rift Valley fever virus infection in camels dromedaries in northern Tanzania. Trop Anim Health Prod 47:347-352. https://doi.org/10.1007/s11250014-0726-y

Tadesse G (2015) A meta-analysis of the proportion of animal Salmonella isolates resistant to drugs used against human salmonellosis in Ethiopia. BMC Infect Dis 15:84. https://doi.org/ 10.1186/s12879-015-0835-x

Tai W, Wang Y, Fett CA, Zhao G, Li F, Perlman S, Jiang S, Zhou Y, Du L (2017) Recombinant Receptor-binding domains of multiple Middle East respiratory syndrome coronaviruses MERS-CoVs induce cross-neutralizing antibodies against divergent human and camel MERS-CoVs and antibody escape mutants. J Virol 91:e01651-16. https://doi.org/10.1128/ JVI.01651-16

Tejedor-Junco MT, González-Martín M, Noé Francisco RG (2015) Identification, antimicrobial susceptibility, and virulence factors of Enterococcus spp. strains isolated from Camels in Canary Islands, Spain. Vet Ital 5:179-183. https://doi.org/ 10.12834 /vetit.322.1280.2

Teshome H, Molla B, Tibbo M (2003) A seroprevalence study of camel brucellosis in three camel-rearing regions of Ethiopia. Trop Anim Health Prod 35:381-390. https://doi.org/10.1023/ A:1025874310261

Tigre W, Deresa B, Haile A, Gabriël S, Victor B, Pelt JV, Devleesschauwer B, Vercruysse J, Dorny P (2016) Molecular characterization of Echinococcus granulosus s.l. cysts from cattle, camels, goats and pigs in Ethiopia. Vet Parasitol 215:17-21. https://doi.org/10.1016/j.vetpar.2015.10.022 
Thompson RCA (2008) The taxonomy, phylogeny and transmission of Echinococcus. Exp Parasitol 119:439-446. https:// doi.org/10.1016/j.exppara.2008.04.016

Utuk AE, Simsek S, Koroglu E, McManus DP (2008) Molecular genetic characterization of different isolates of Echinococcus granulosus in east and southeast regions of Turkey. Acta Trop 107:192-194. https://doi.org/10.1016/j.actatropica.2008.05.026

Vanderburg S, Rubach MP, Halliday JEB, Cleaveland S, Reddy EA, Crump JA (2014) Epidemiology of Coxiella burnetii infection in Africa: a onehealth systematic review. PLoS Neglected Tropical Diseases 8:e2787. https://doi.org/10.1371/journal.pntd.0002787

Wachira TM, Bowles J, Zeyhle E, McManus DP (1993) Molecular examination of the sympatry and distribution of sheep and camel strains of Echinococcus granulosus in Kenya. Am J Trop Med Hyg 48:473-479. https://doi.org/10.4269/ajtmh.1993. 48.473

Walker PJ, Widen SG, Wood TG, Guzman H, Tesh RB, Vasilakis $\mathrm{N}$ (2016) A global genomic characterization of nairoviruses identifies nine discrete genogroups with distinctive structural characteristics and Host-Vector Associations. Am J Trop Med Hyg 94:1107-1122. https://doi.org/10.4269/ajtmh.15-0917

Watson JT, Hall AJ, Erdman DD, Swerdlow DL, Gerber SI (2014) Unraveling the Mysteries of Middle East respiratory syndrome coronavirus. Emerg Infect Dis 20:1054-1056. https://doi.org/ 10.3201/eid2006.140322

Watson EE, Kochore HH, Dabasso BH (2016) Camels and climate resilience: adaptation in Northern Kenya. Human Ecology 44:701-713. https://doi.org/10.1007/s10745-016-9858-1

Weaver SC, Reisen WK (2010) Present and future arboviral threats. Antivir Res 85:328-345. https://doi.org/10.1016/j.antiviral.2009.10.008

Wernery U (2014) Camelid brucellosis: a review. Revue Scientifique Et Technique Int Off Epizootics 33:839-857

Wernery U, Corman VM, Wong EYM, Tsang AKL, Muth D, Lau SKP, Khazanehdari K, Zirkel F, Ali M, Nagy P, Juhasz J, Wernery R, Joseph S, Syriac G, Elizabeth SK, Patteril NAG, Woo PCY, Drosten C (2015) Acute Middle East respiratory syndrome coronavirus infection in Livestock Dromedaries, Dubai, 2014. Emerg Infect Dis 21:1019-1022. https://doi.org/10.3201/ eid2106.150038

Wernery U, Lau SKP, Woo PCY (2016) Genomics and zoonotic infections: Middle East respiratory syndrome. Revue Scientifique et Technique de l'OIE Int Off Epizootics 35:191-202. https:// doi.org/10.20506/rst.35.1.2427

Widagdo W, Raj VS, Schipper D, Kolijn K, van Leenders GJLH, Bosch BJ, Bensaid A, Segalés J, Baumgärtner W, Osterhaus ADME, Koopmans MP, van den Brand JMA, Haagmans BL (2016) Differential expression of the Middle East respiratory syndrome coronavirus receptor in the upper respiratory tracts of humans and dromedary camels. J Virol 90:4838-4842. https:// doi.org/10.1128/JVI.02994-15

de Wit E, van Doremalen N, Falzarano D, Munster VJ (2016) SARS and MERS: recent insights into emerging coronaviruses. Nat Rev Microbiol 14:523-534. https://doi.org/10.1038/nrmicro.2016.81

de Wit E, Munster VJ (2013) MERS-CoV: the intermediate host identified? Lancet Infect Dis 13:827-828. https://doi.org/10.1016/ S1473-30991370193-2

Woo PCY, Lau SKP, Wernery U, Wong EYM, Tsang AKL, Johnson B, Yip CCY, Lau CCY, Sivakumar S, Cai J-P, Fan RYY, Chan K-H, Mareena R, Yuen K-Y (2014) Novel betacoronavirus in dromedaries of the Middle East, 2013. Emerg Infect Dis 20:560-572. https://doi.org/10.3201/eid2004.131769

Woods CW, Ospanov K, Myrzabekov A, Favorov M, Plikaytis B, Ashford DA (2004) Risk factors for human anthrax among contacts of anthrax-infected livestock in Kazakhstan. Am J Trop Med Hyg 71:48-52. https://doi.org/10.4269/ajtmh.2004.71.48

World Health Organization (2015) Middle East respiratory syndrome coronavirus MERS-CoV summary of current situation, literature update and risk assessment-7 July 2015, Geneva: $\mathrm{WHO}$

World Health Organization (2016) Clinical management of patients with viral haemorrhagic fever: a pocket guide for front-line health workers: interim emergency guidance for country adaption, Geneva: WHO

World Health Organization (2017) Middle East respiratory syndrome coronavirus MERS-CoV Summary of current situation, literature update and risk assessment -21 July 2017, Geneva: WHO

Yahya BAI (2015) Sero-epidemiological study of camel brucellosis Camelus dromedarius and associated risk factors in the Butana plain area and Al-gadarief state-Sudan. Thesis, Sudan University of Science and Technology

Younan M, Bornstein S, Gluecks IV (2016) MERS and the dromedary camel trade between Africa and the Middle East. Trop Anim Health Prod 48:1277-1282. https://doi.org/10.1007/ s11250-016-1089-3

Youssef AI, Uga S (2014) Review of parasitic zoonoses in Egypt. Trop Med Health 42:3-14. https://doi.org/10.2149/tmh.2013-23

Yusof MF, Eltahir YM, Serhan WS, Hashem FM, Elsayed EA, Marzoug BA, Abdelazim AS, Bensalah OKA, Al Muhairi SS (2015) Prevalence of Middle East respiratory syndrome coronavirus MERS-CoV in dromedary camels in Abu Dhabi Emirate, United Arab Emirates. Virus Genes 50:509-513. https://doi.org/ 10.1007/s11262-015-1174-0

Zewolda SW, Wereta MH (2012) Seroprevalence of brucella infection in camel and its public health significance in selected districts of Afar region, Ethiopia. J Environ Occup Sci 1(2):91-98

Zhang LH, Chai JJ, Jiao W, Osman Y, McManus DP (1998) Mitochondrial genomic markers confirm the presence of the camel strain G6 genotype of Echinococcus granulosus in north-western China. Parasitology 116:29-33

Zhang W, McManus DP (2006) Recent advances in the immunology and diagnosis of echinococcosis. FEMS Immunol Med Microbiol 47:24-41. https://doi.org/10.1111/j.1574695X.2006.00060.x

Zhang Z, Shen L, Gu X (2016) evolutionary Dynamics of MERS$\mathrm{CoV}$ : potential recombination, positive selection and transmission. Sci Rep 6:25049. https://doi.org/10.1038/srep25049

Zumla A, Dar O, Kock R, Muturi M, Ntoumi F, Kaleebu P, Eusebio M, Mfinanga S, Bates M, Mwaba P, Ansumana R, Khan M, Alagaili AN, Cotten M, Azhar EI, Maeurer M, Ippolito G, Petersen E (2016) Taking forward a 'One Health' approach for turning the tide against the Middle East respiratory syndrome coronavirus and other zoonotic pathogens with epidemic potential. Int J Infect Dis 47:5-9. https://doi.org/10.1016/ j.ijid.2016.06.012

Zumla A, Hui DS, Perlman S (2015) Middle East respiratory syndrome. Lancet 386:995-1007. https://doi.org/10.1016/S014067361560454-8

Zumla AI, Memish ZA (2014) Middle East respiratory syndrome coronavirus: epidemic potential or a storm in a teacup? Eur Respir J 43:1243-1248. https://doi.org/10.1183/09031936.00227213 